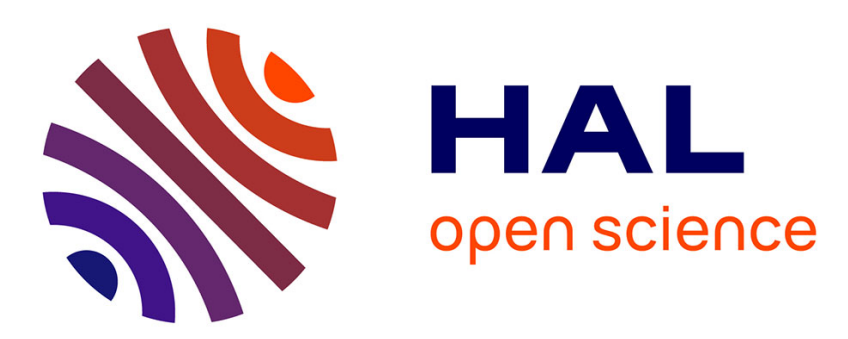

\title{
The position of Tubu women in pastoral production: Daza Kesherda, Republic of Niger
}

\author{
Catherine Baroin
}

\section{To cite this version:}

Catherine Baroin. The position of Tubu women in pastoral production: Daza Kesherda, Republic of Niger. Ethnos (Stockholm), 1987, 1-2, pp.137-155. halshs-00876299

\section{HAL Id: halshs-00876299 \\ https://shs.hal.science/halshs-00876299}

Submitted on 24 Oct 2013

HAL is a multi-disciplinary open access archive for the deposit and dissemination of scientific research documents, whether they are published or not. The documents may come from teaching and research institutions in France or abroad, or from public or private research centers.
L'archive ouverte pluridisciplinaire HAL, est destinée au dépôt et à la diffusion de documents scientifiques de niveau recherche, publiés ou non, émanant des établissements d'enseignement et de recherche français ou étrangers, des laboratoires publics ou privés. 


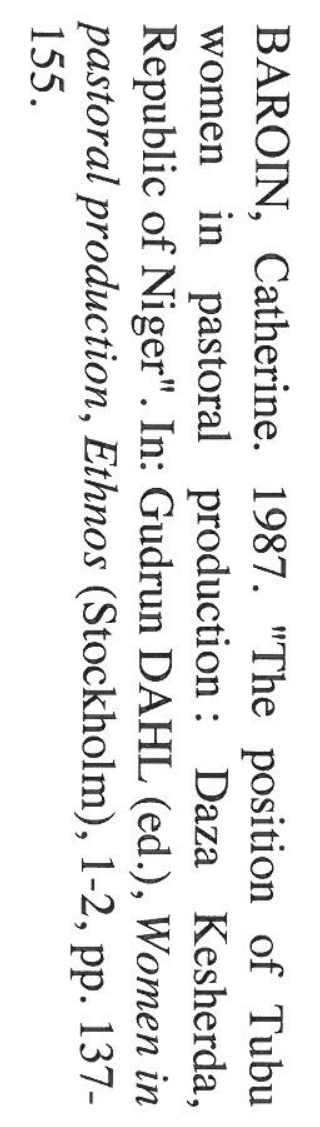

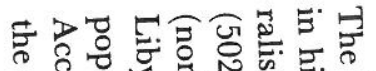

영

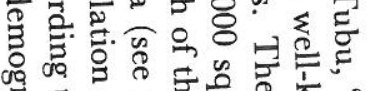

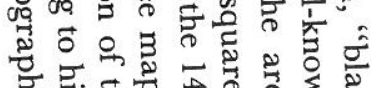

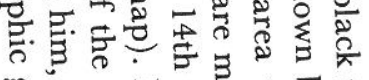

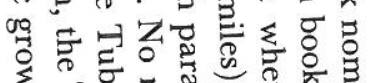

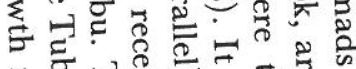

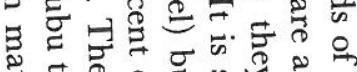

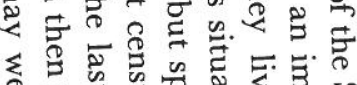

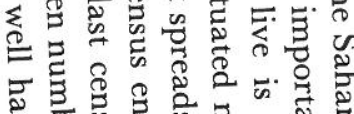

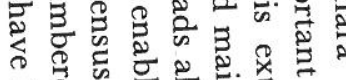
ठ

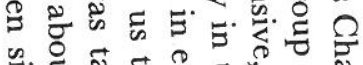

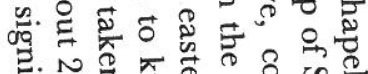

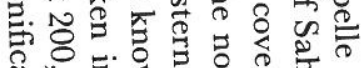

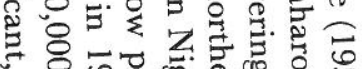
5

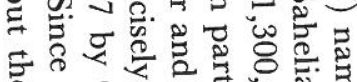

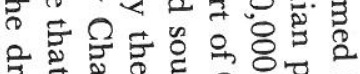

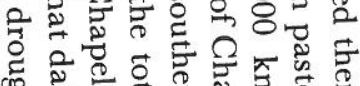

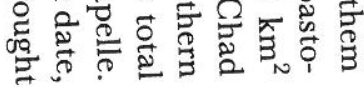

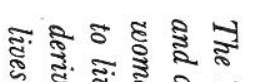

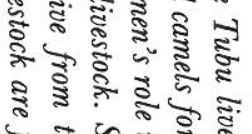

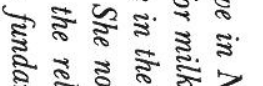

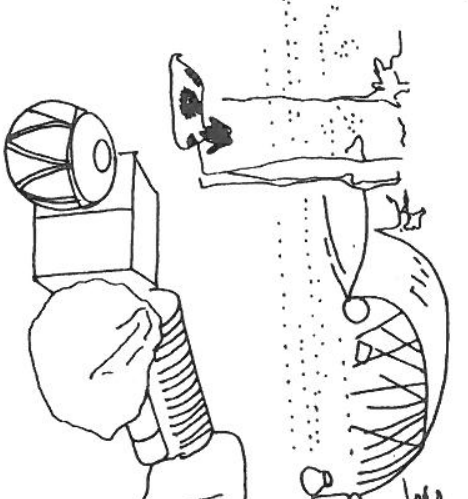

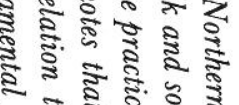

कात्र

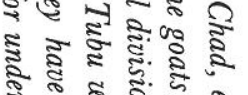

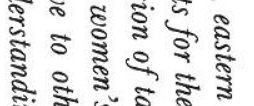

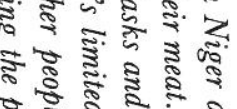

क्ष.:

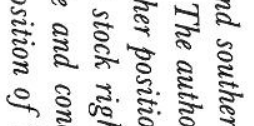

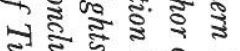

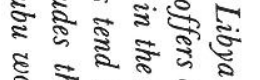
क्व

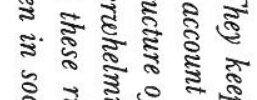

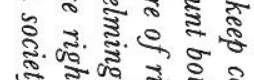

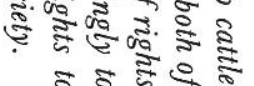

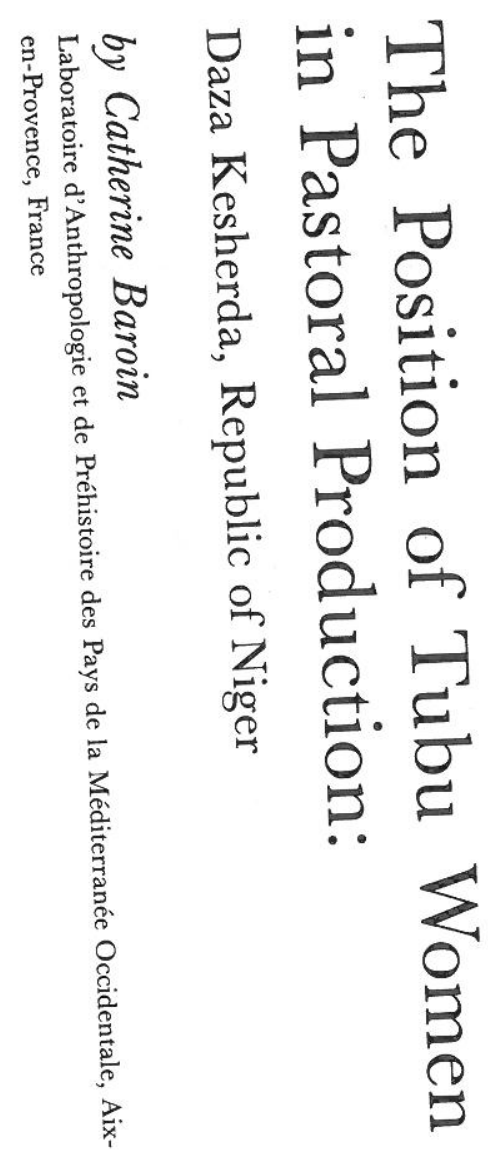




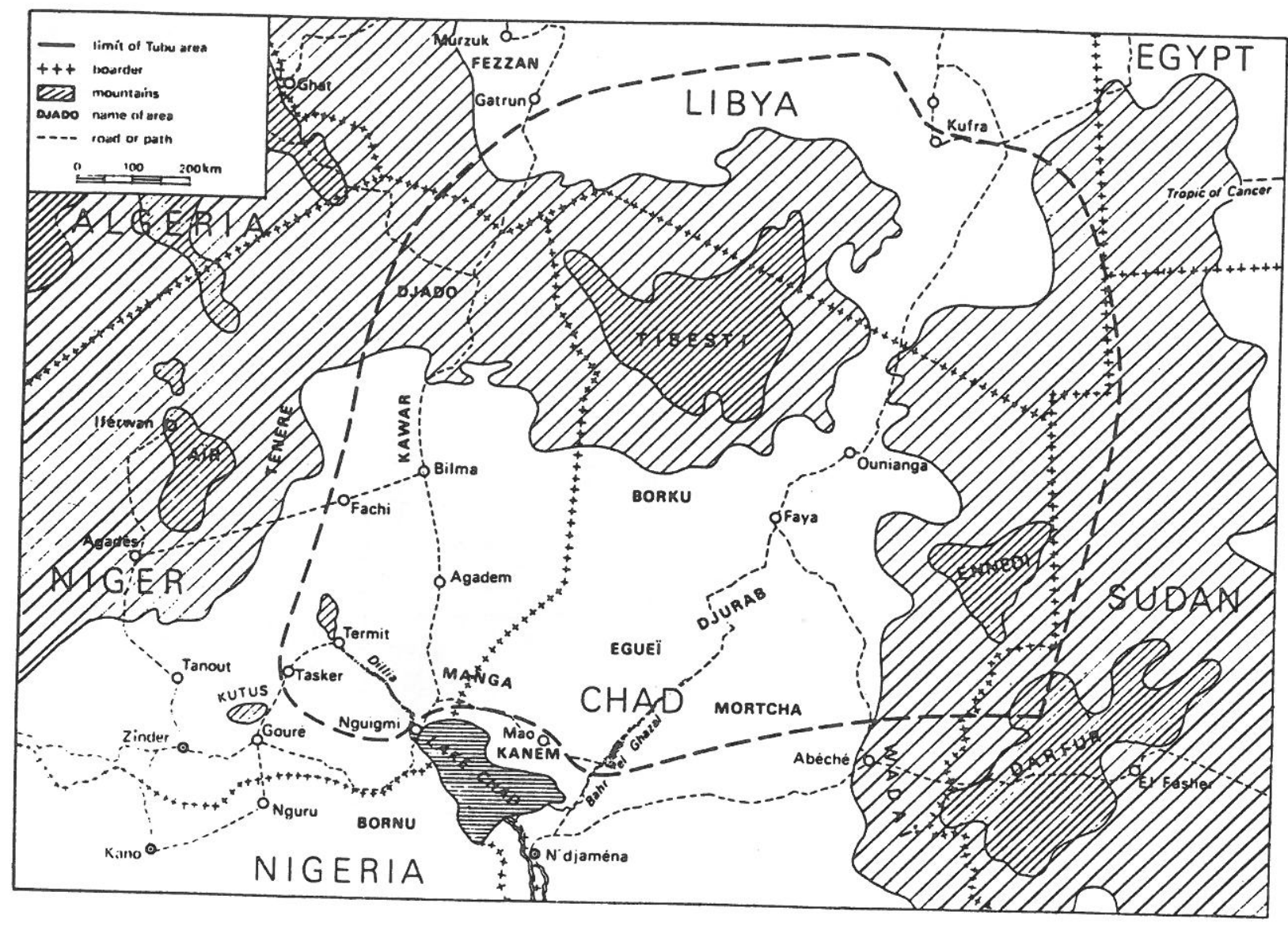

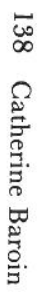

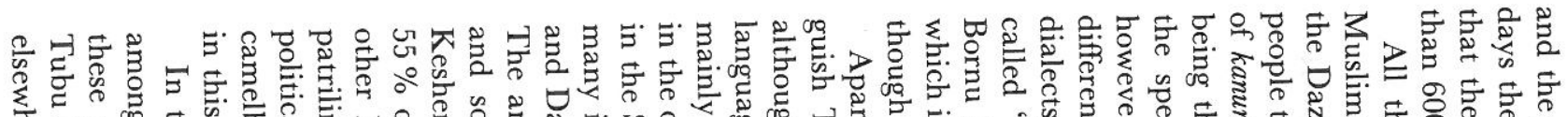

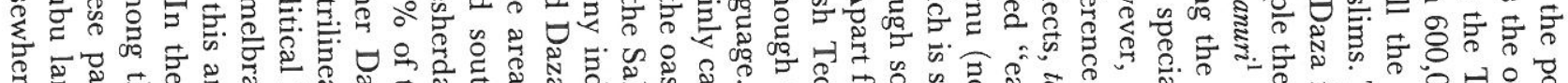

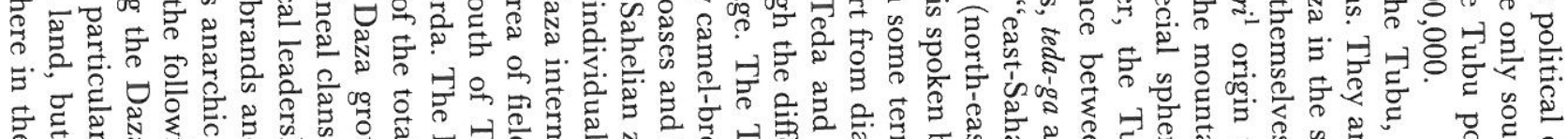

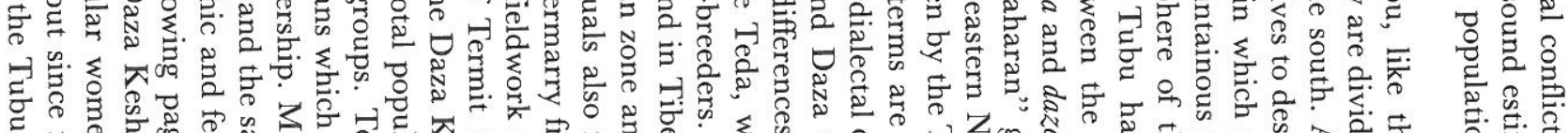

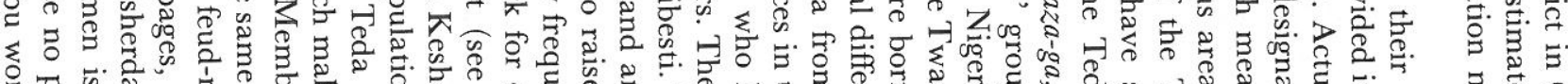

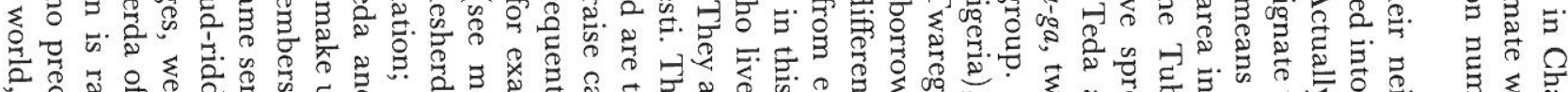

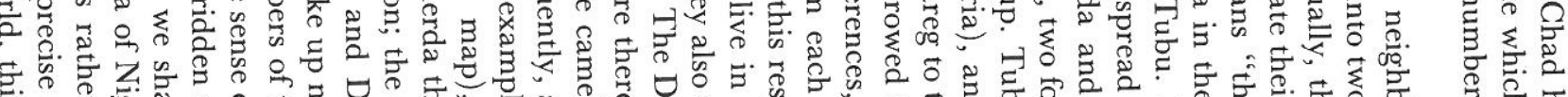

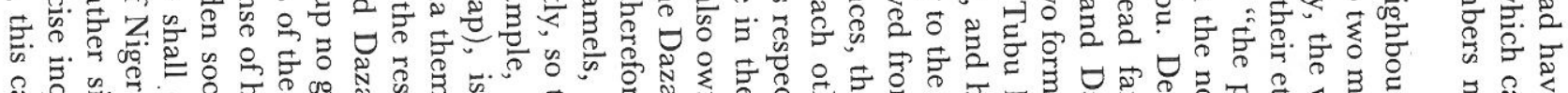

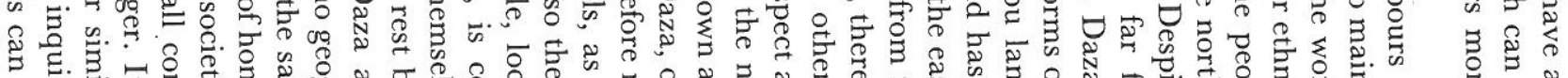

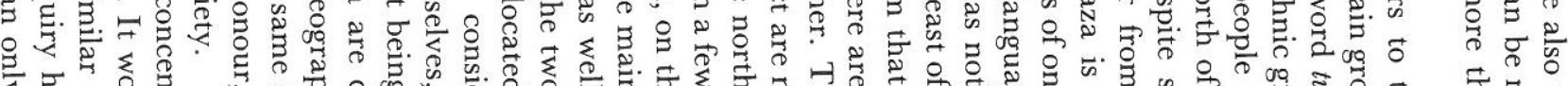

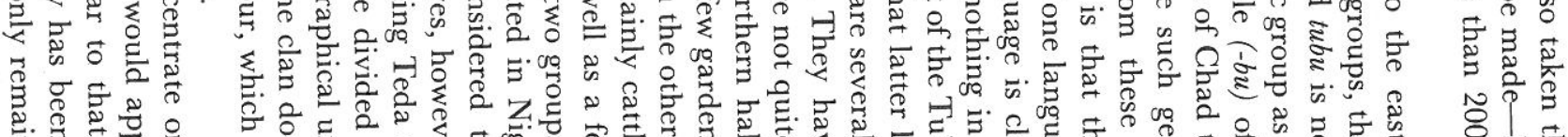

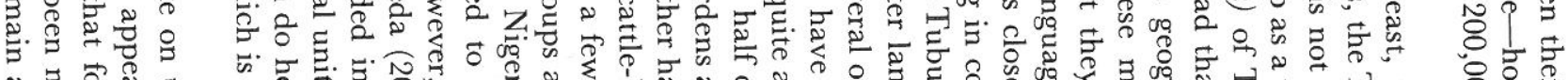

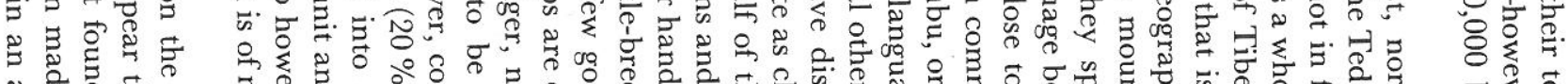

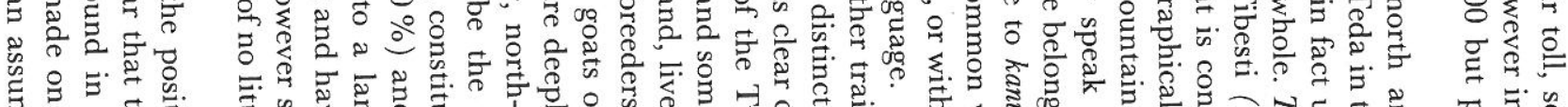

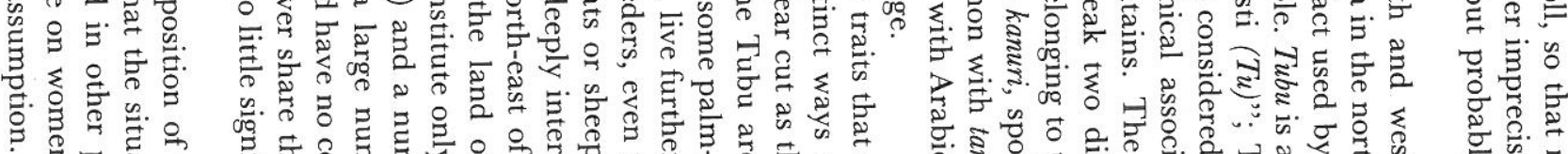

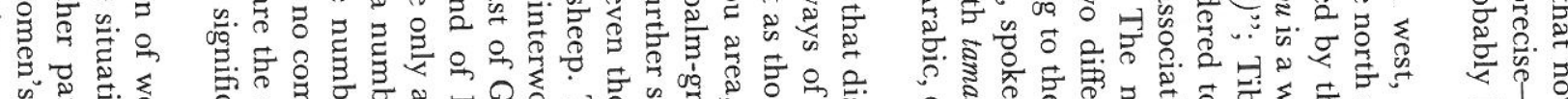

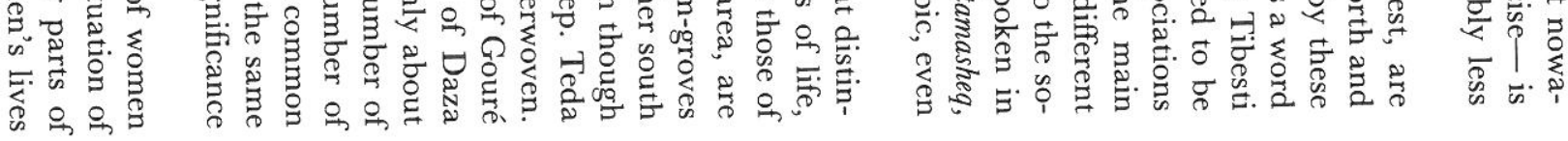




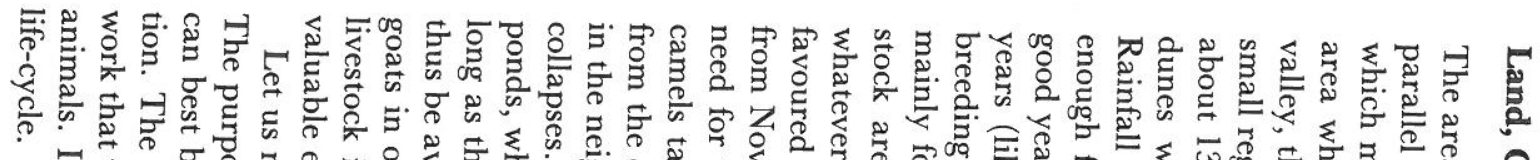

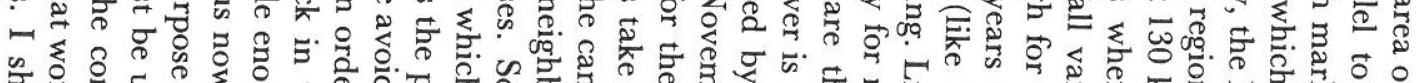

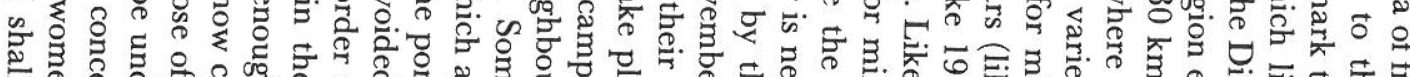
=

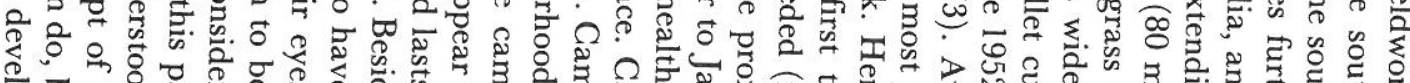

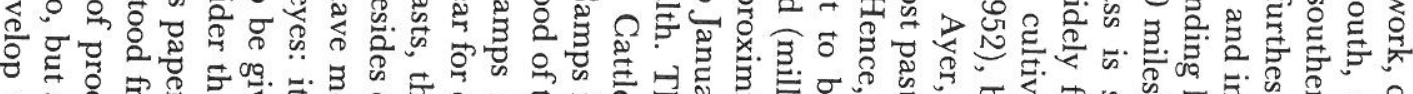

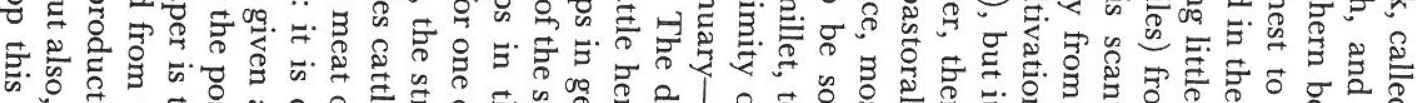

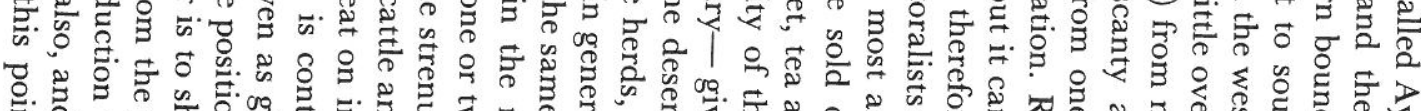

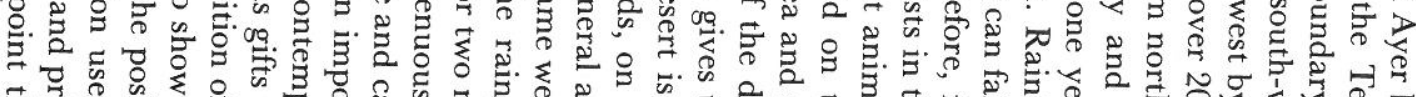

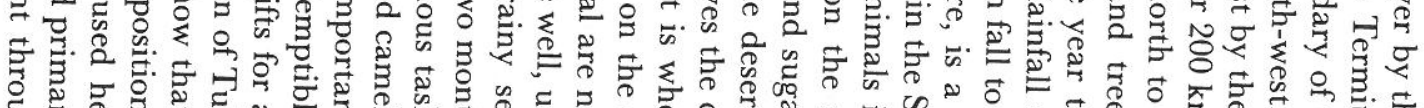

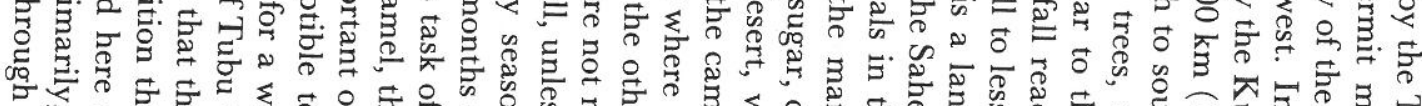

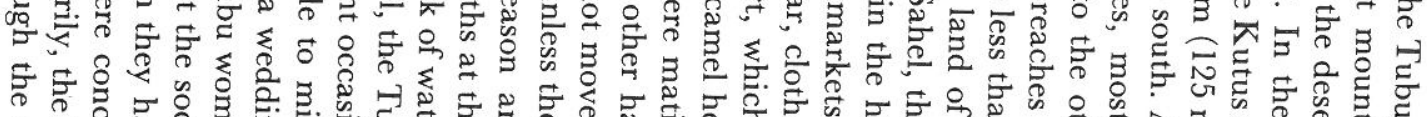

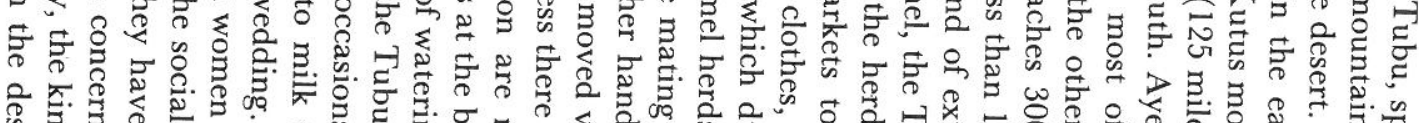

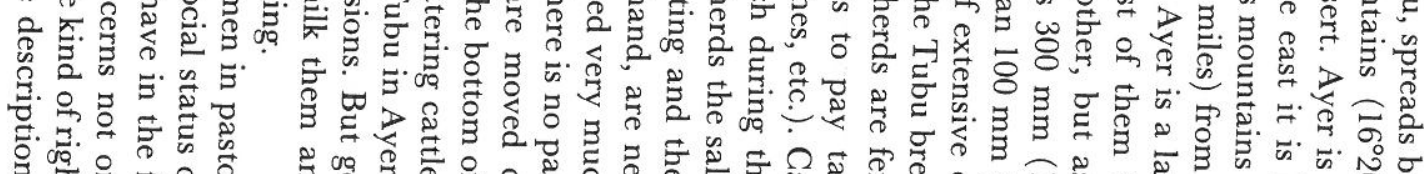

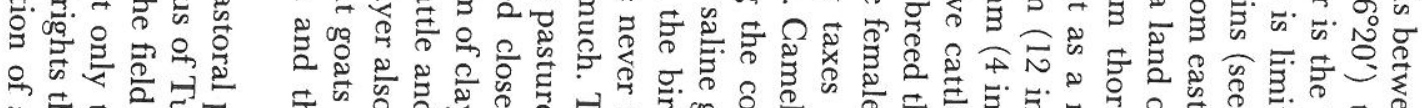

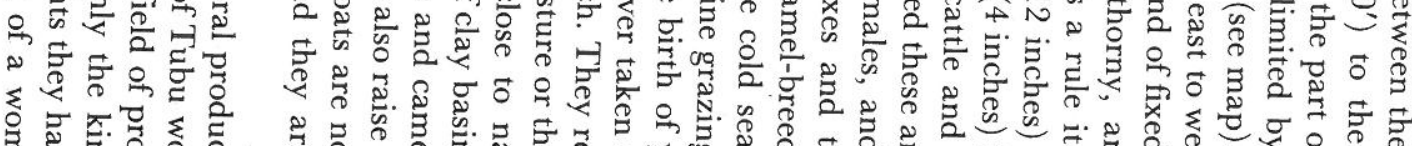

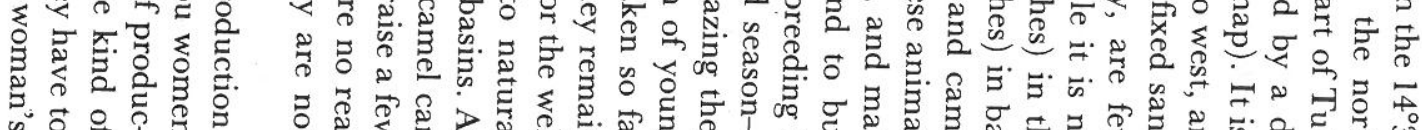

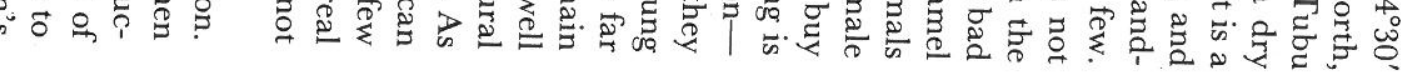

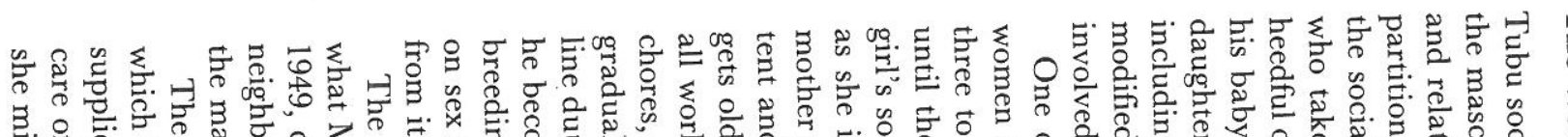

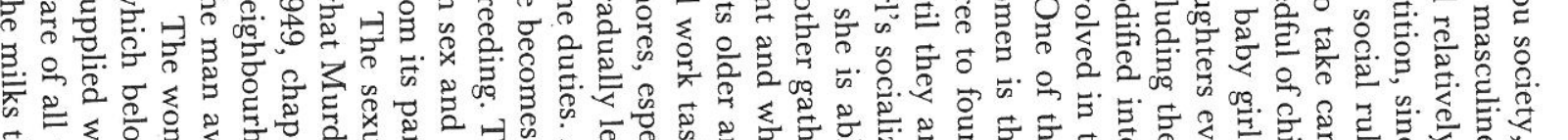

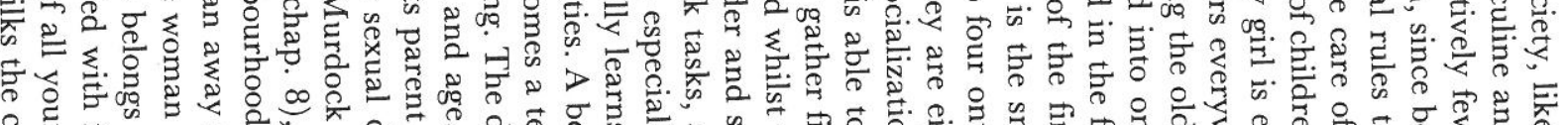

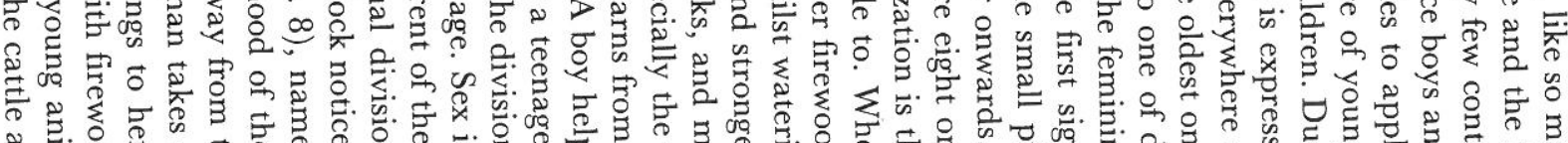
4

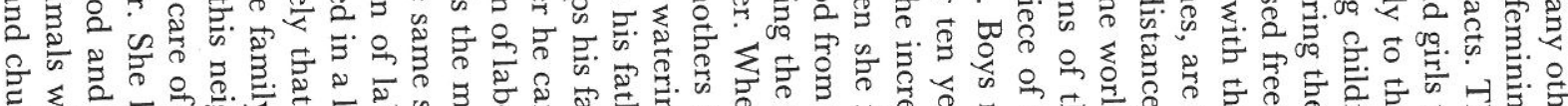

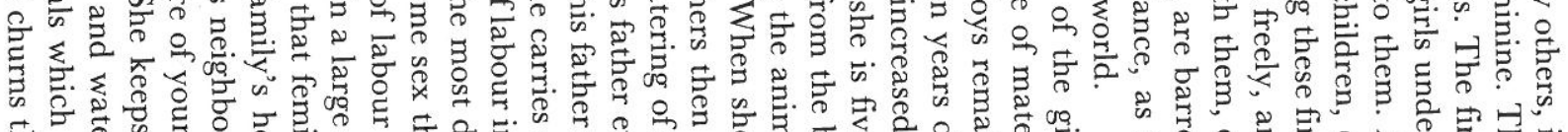

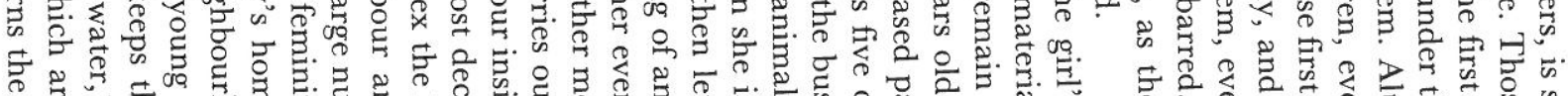

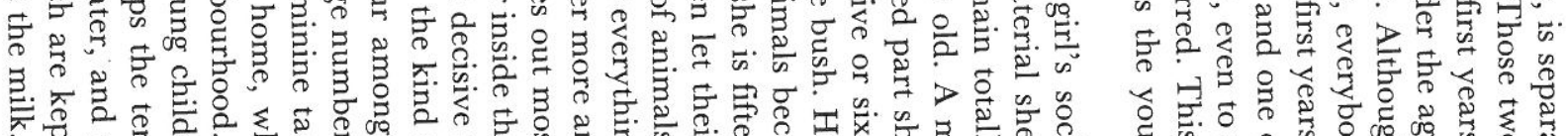

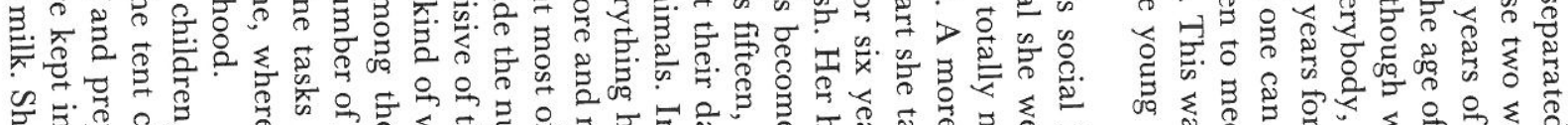

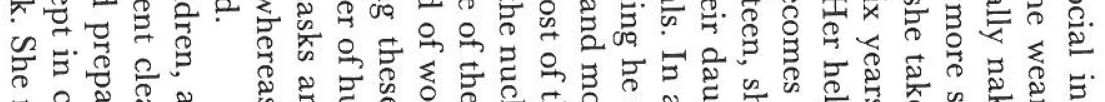

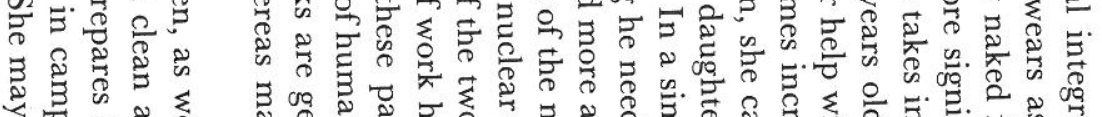

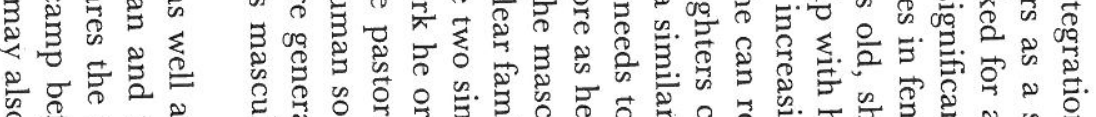
फo

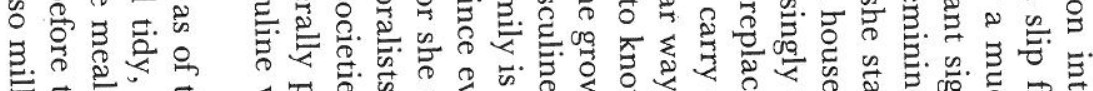

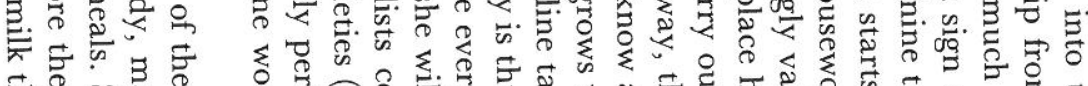

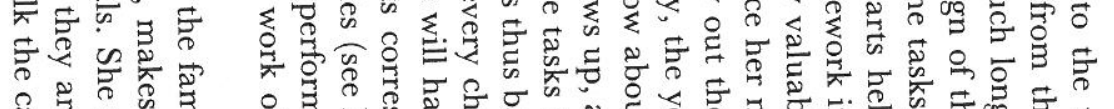

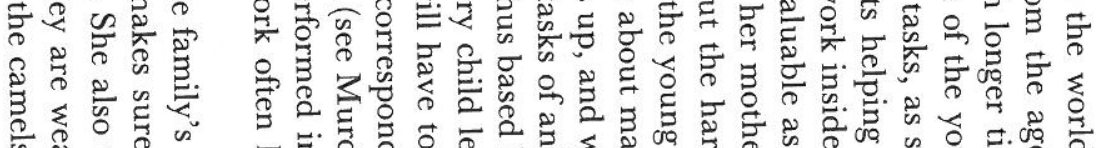

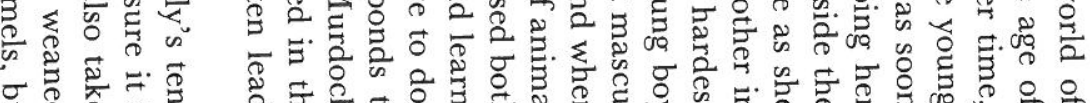

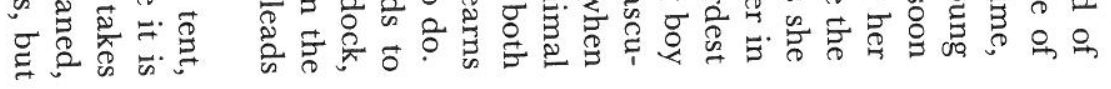

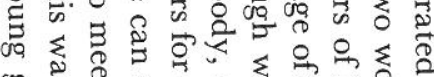

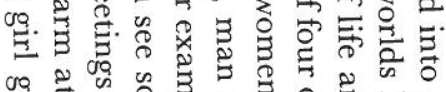

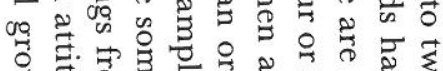

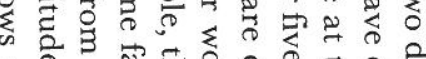

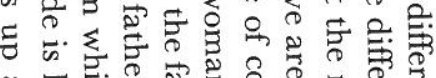

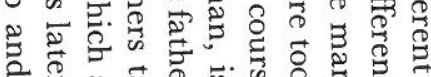

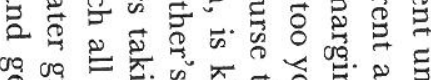
og og 6.

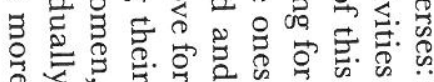




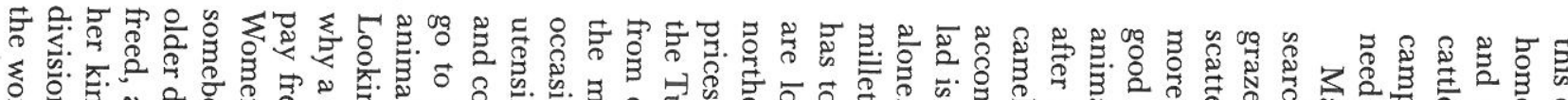

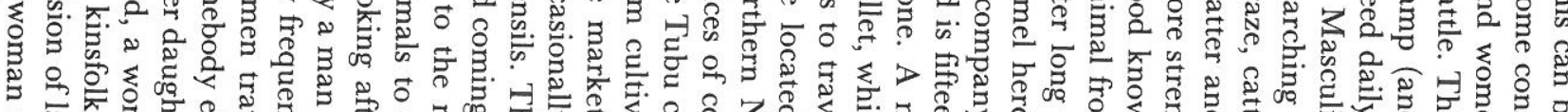
б

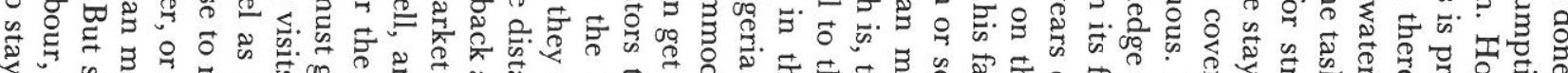

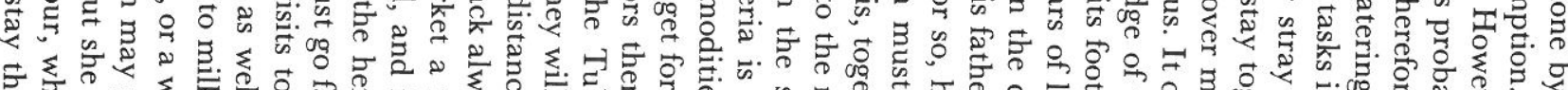

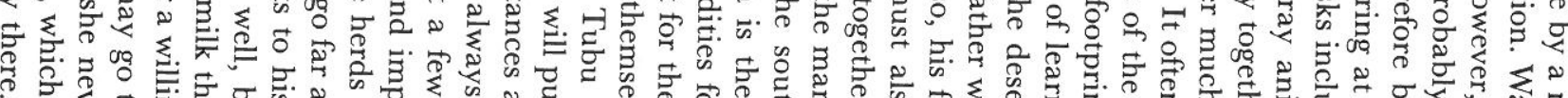

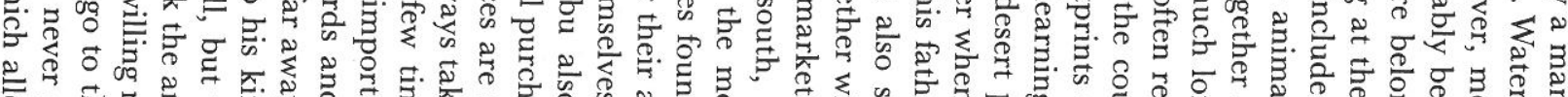

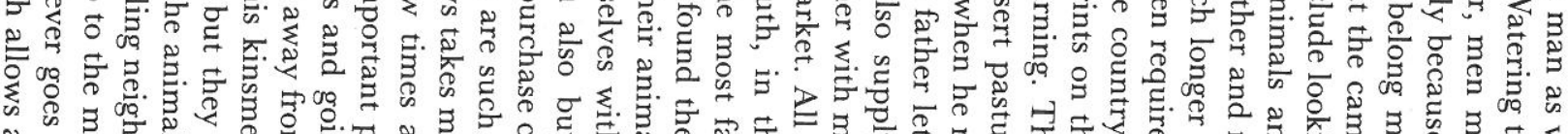

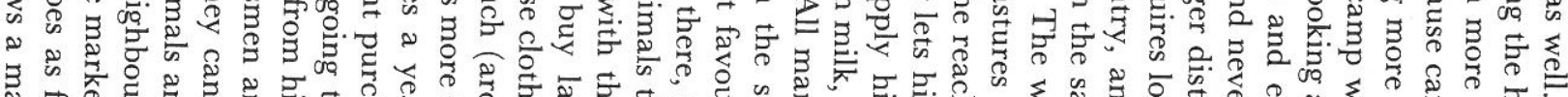

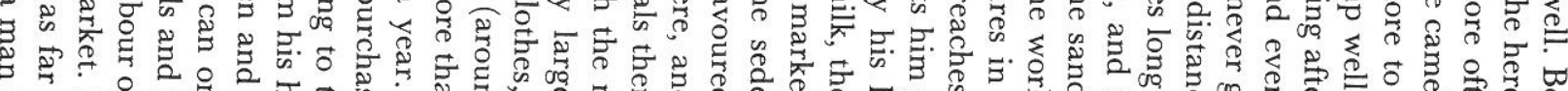

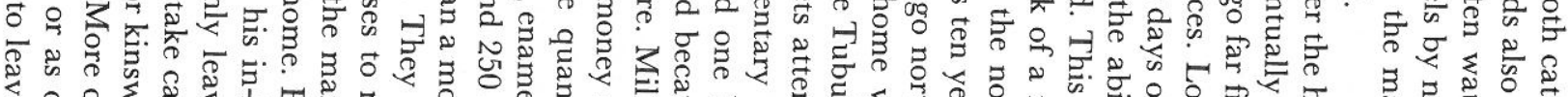

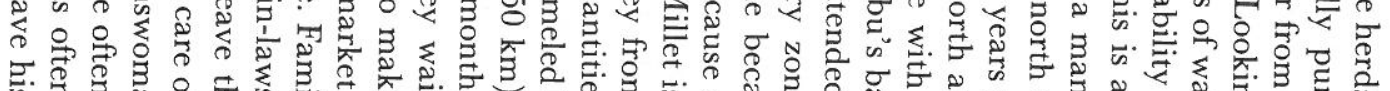

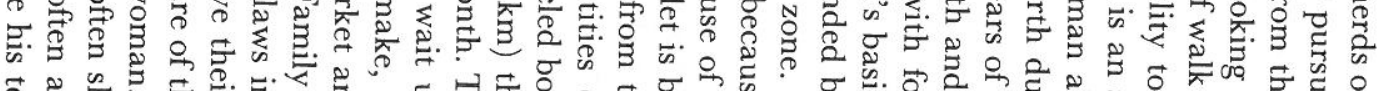

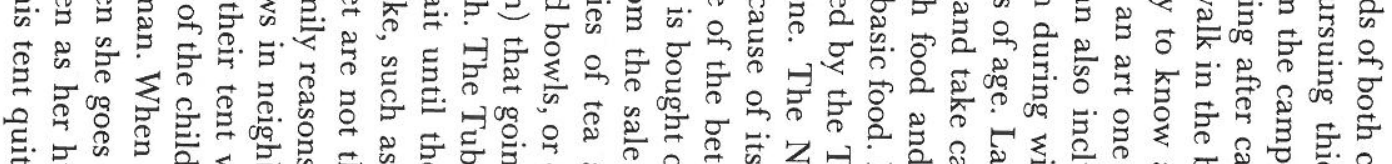

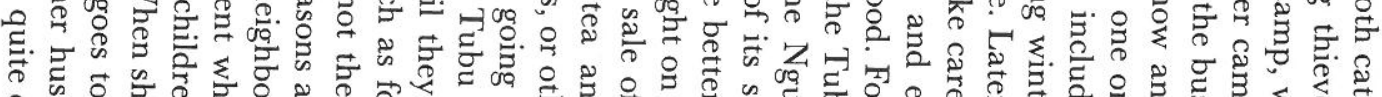

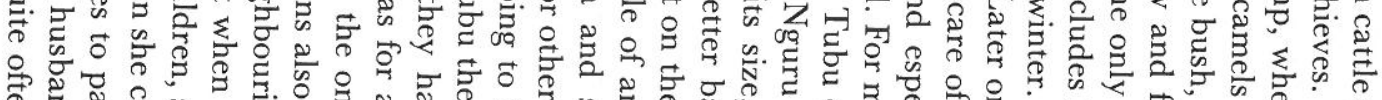

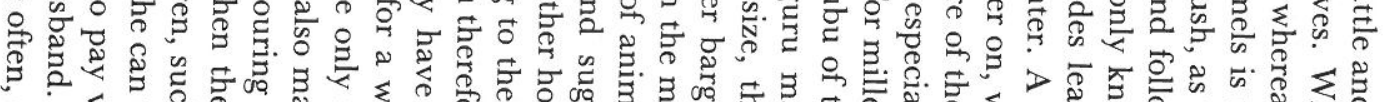

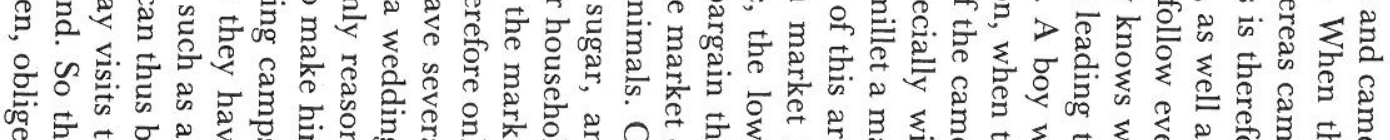

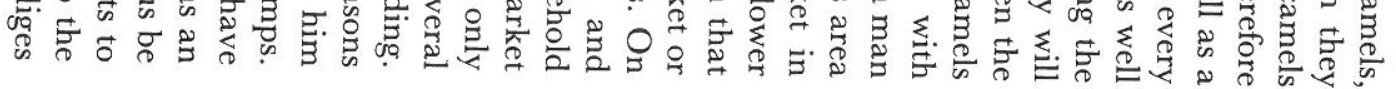

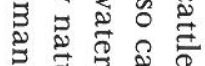

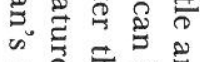

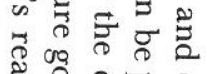

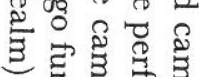

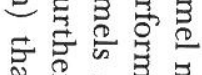
政

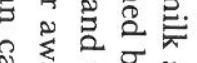

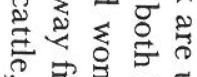

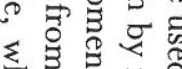

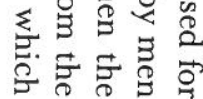

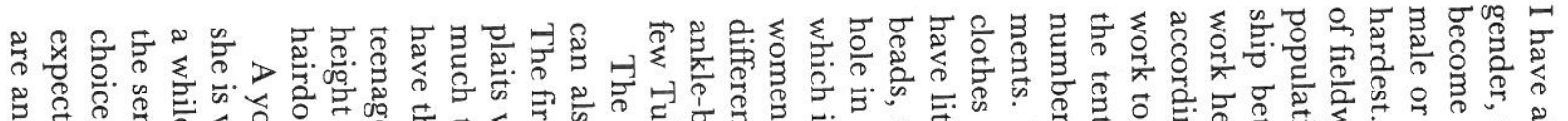

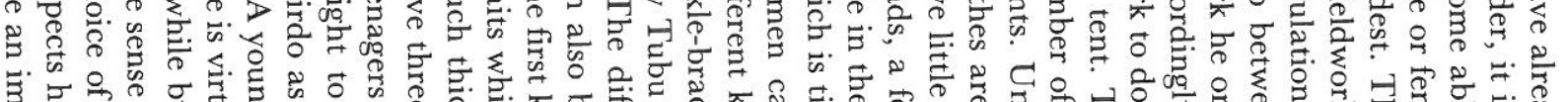

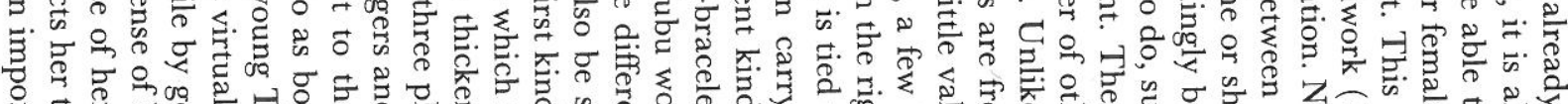
然

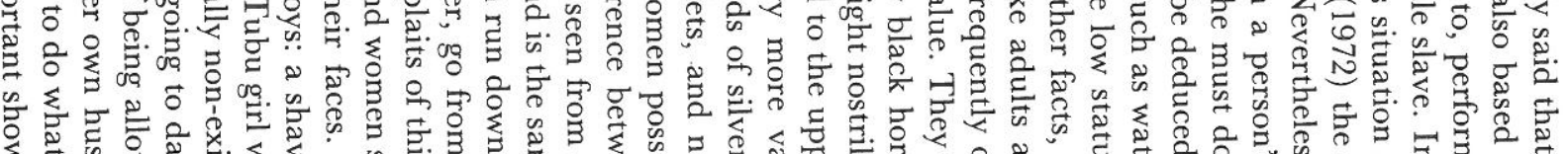

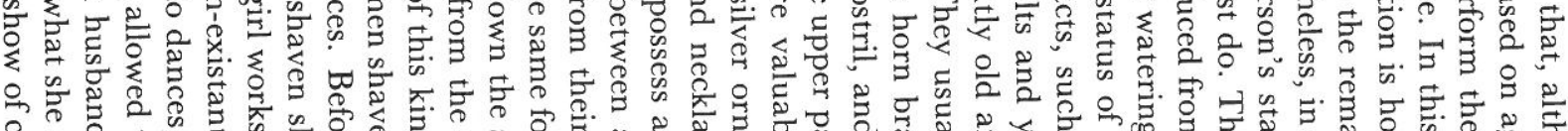

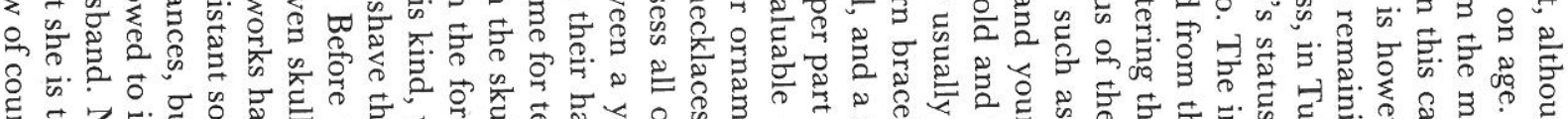

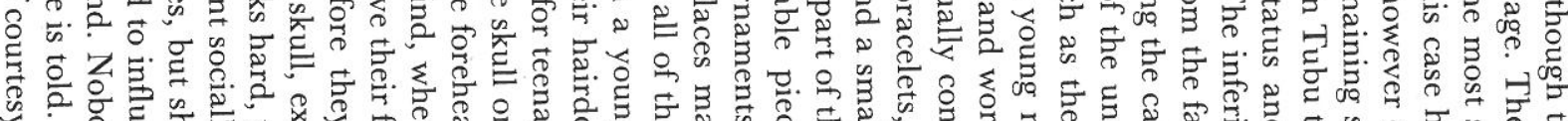

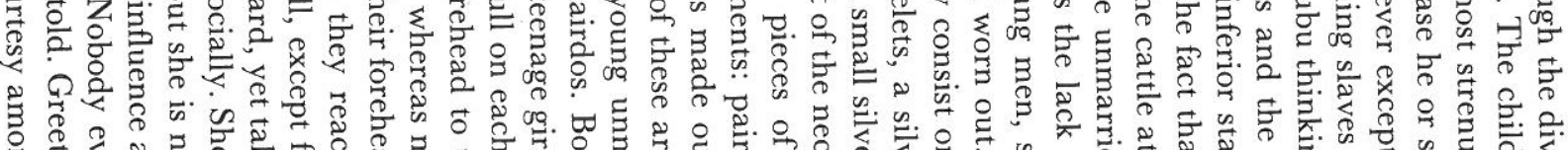

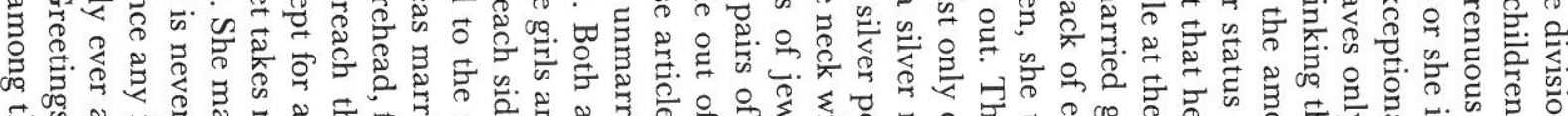

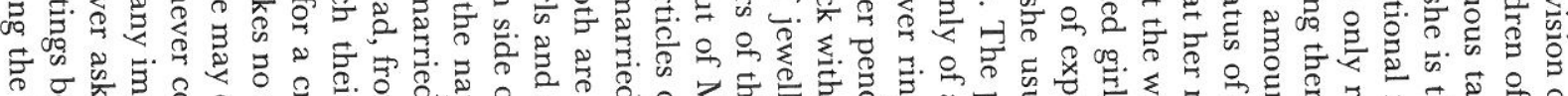

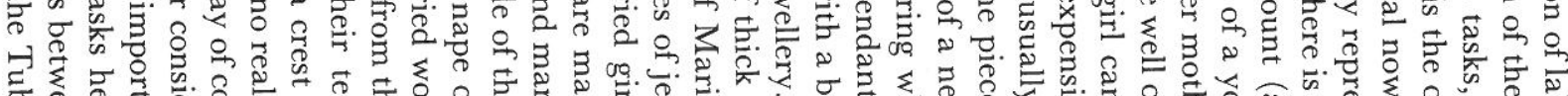

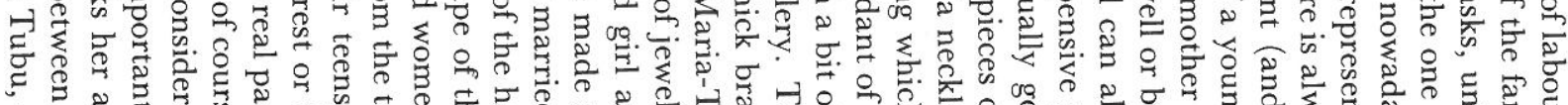

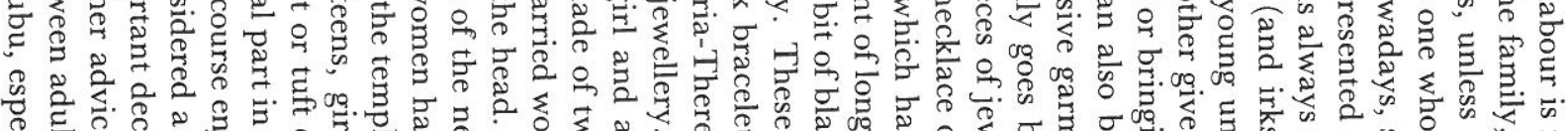

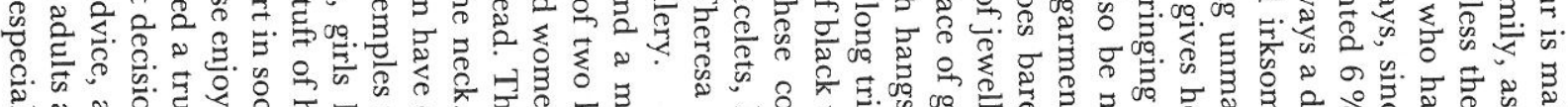

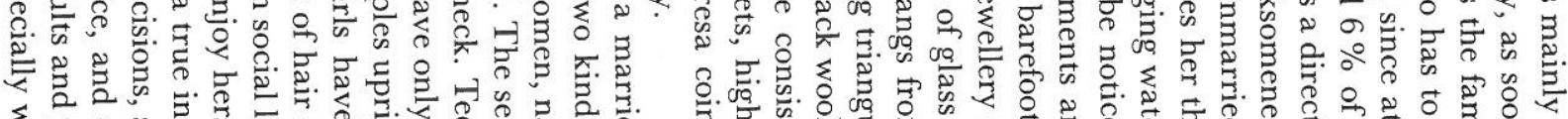

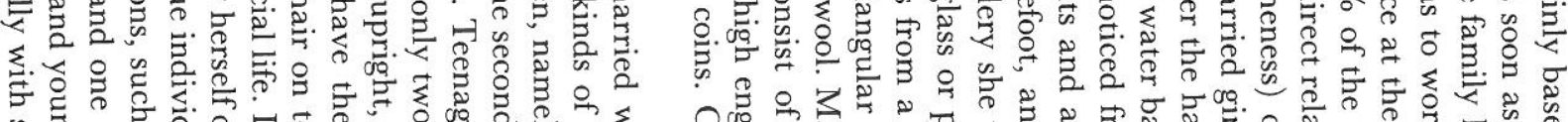

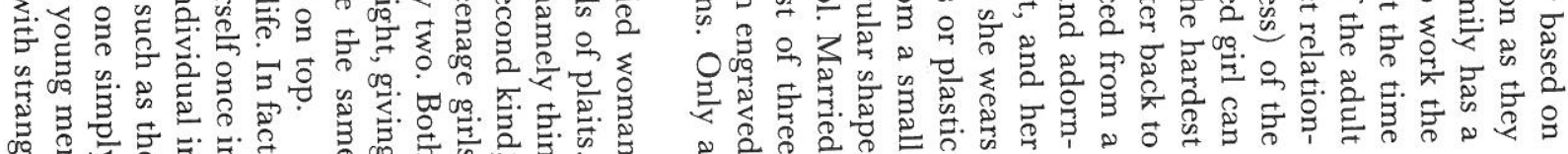
焉

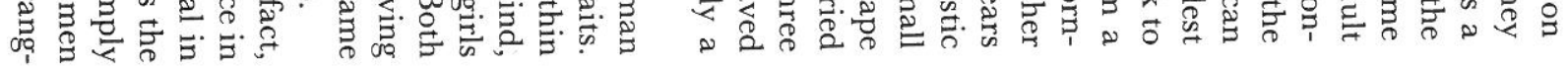




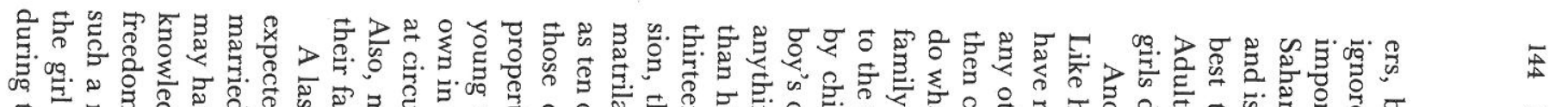

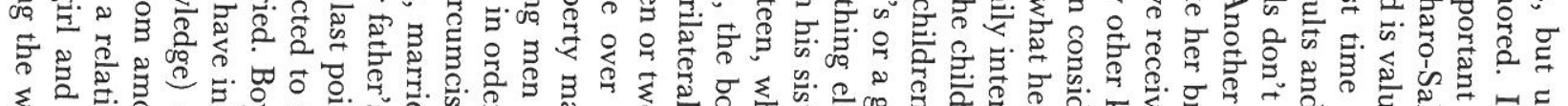

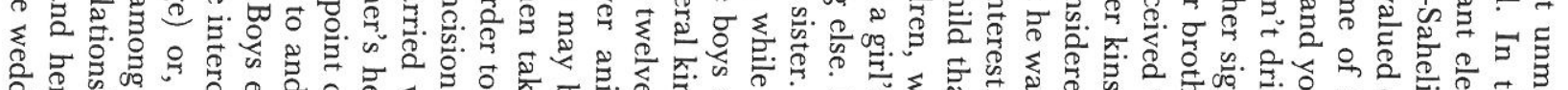

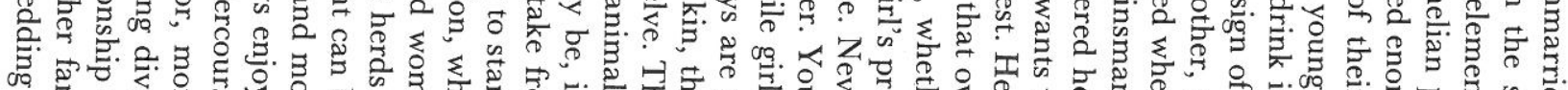

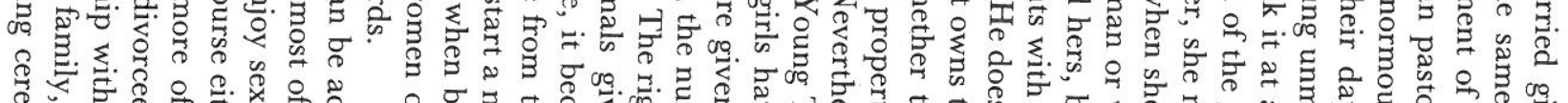

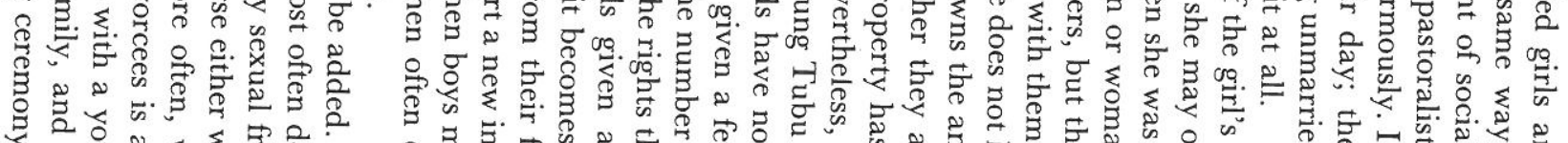
(3)

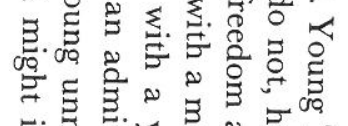

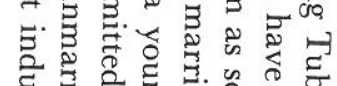

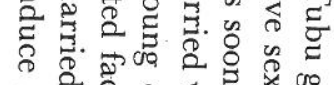

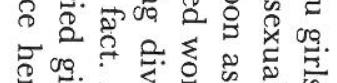

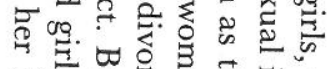

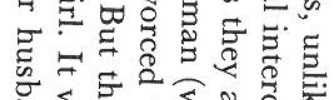

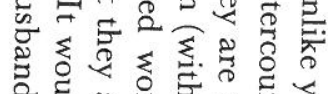

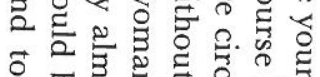

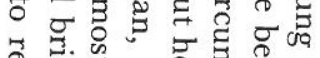

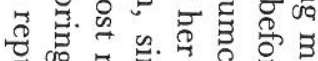

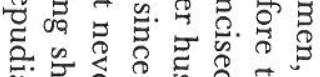

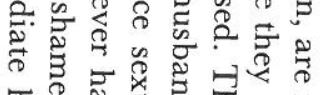

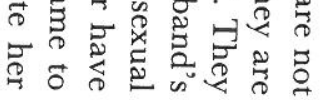

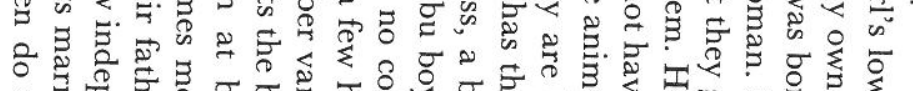

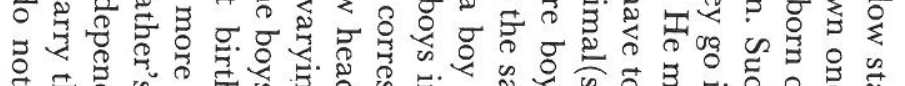

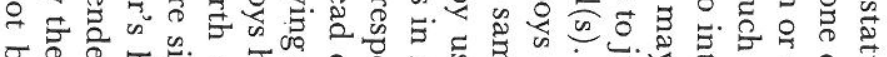

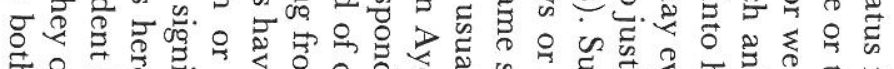

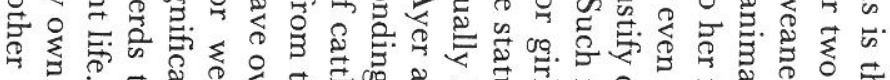

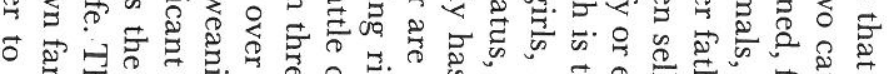

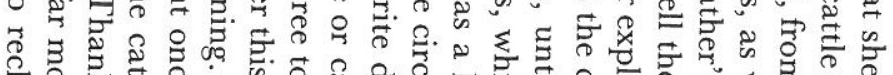
.

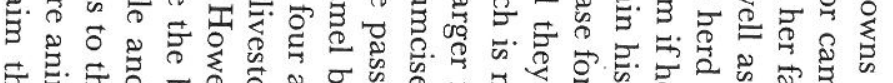

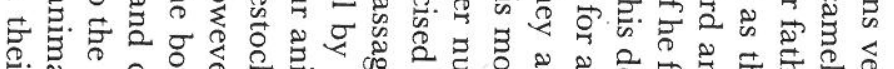

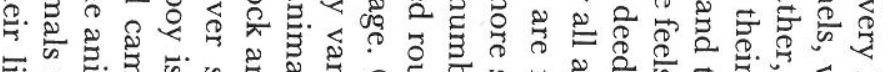

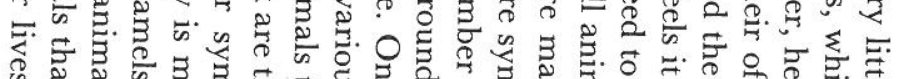

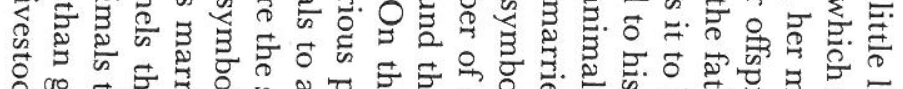

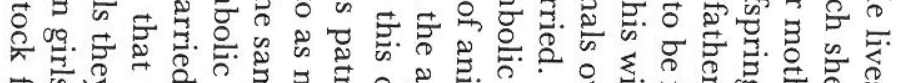

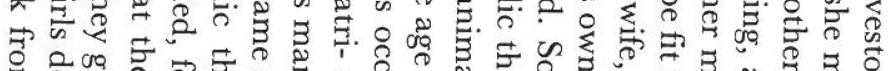

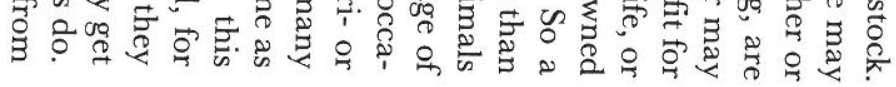

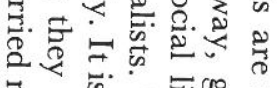

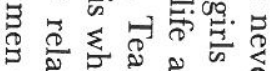

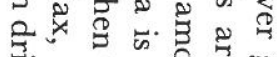

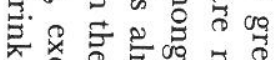

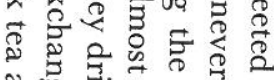

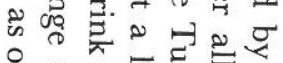

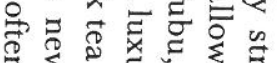

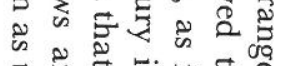

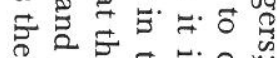

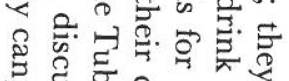

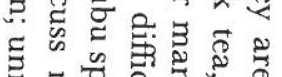
娄

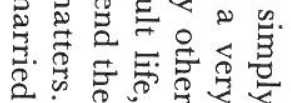

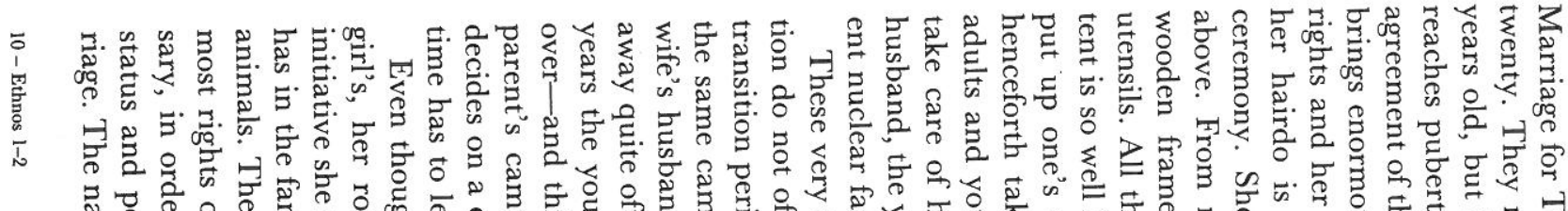

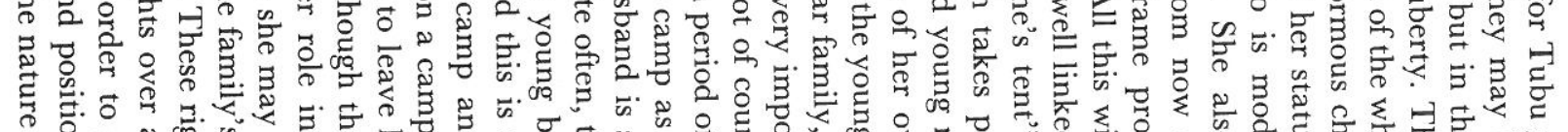

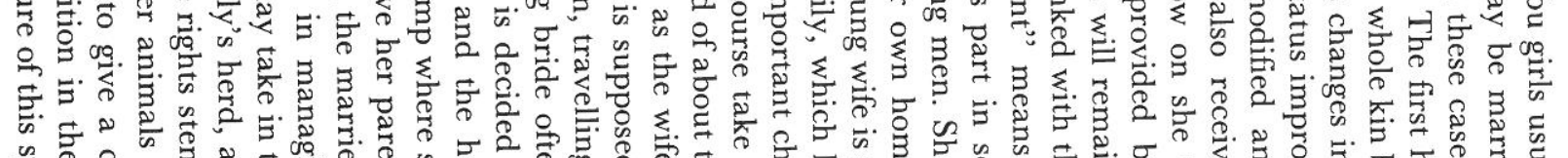

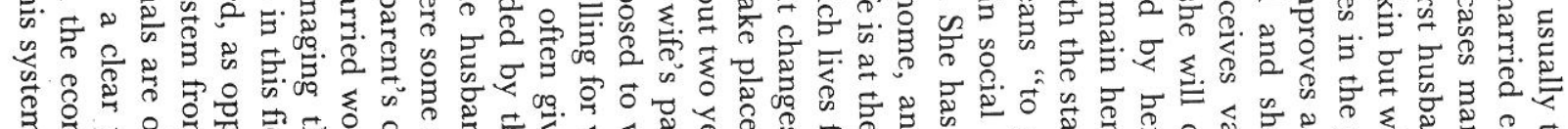

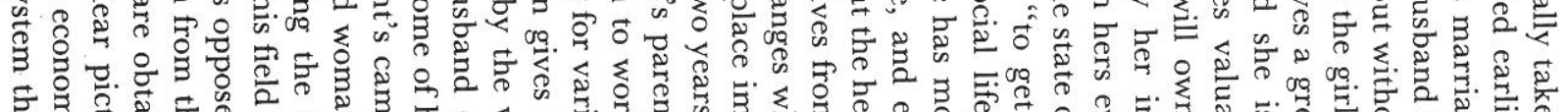

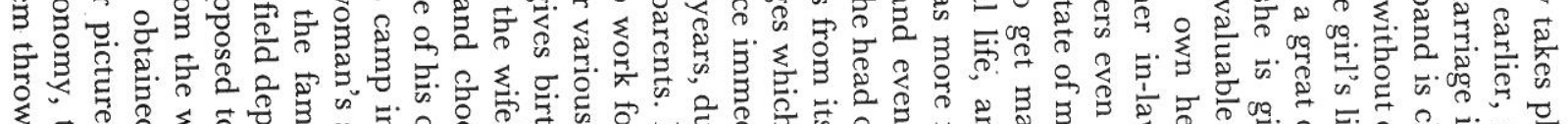

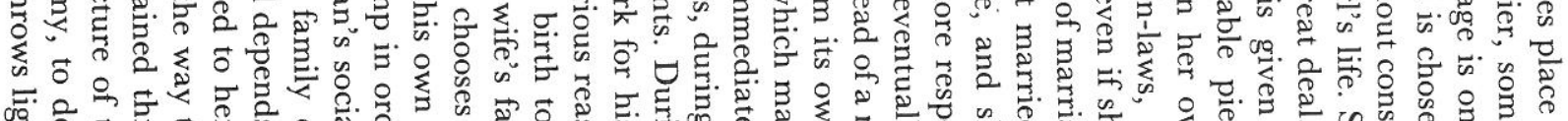

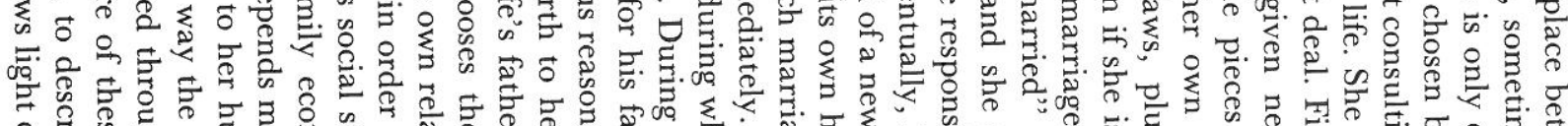

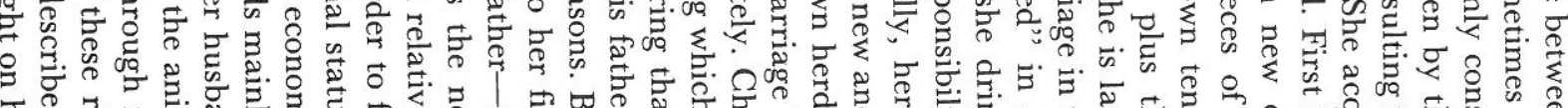

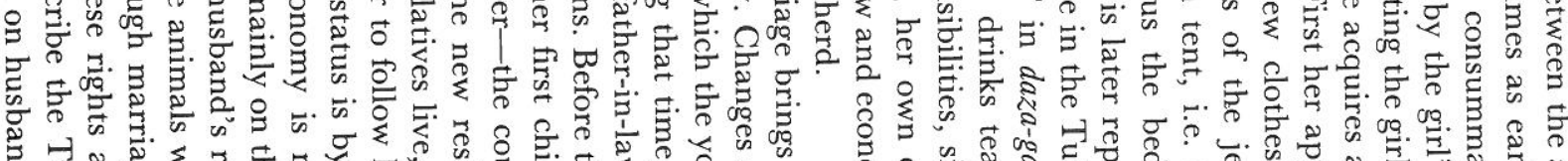

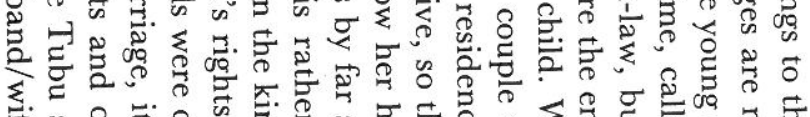

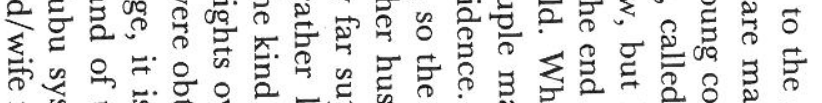

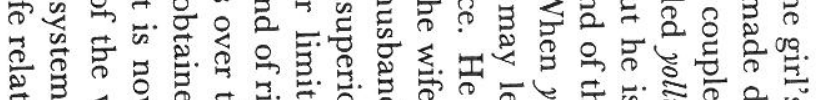

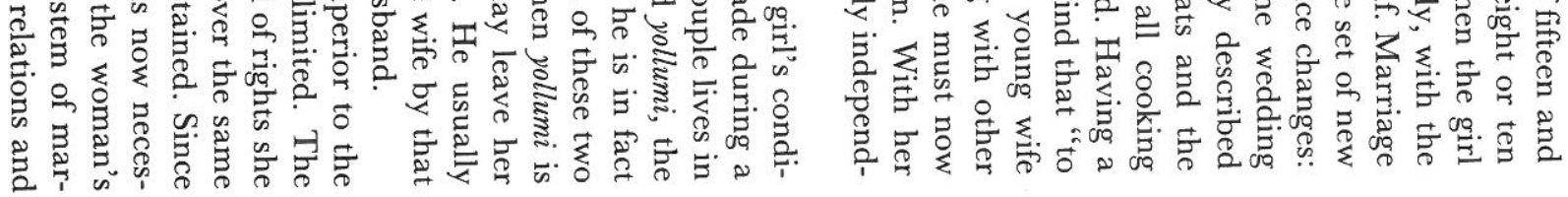

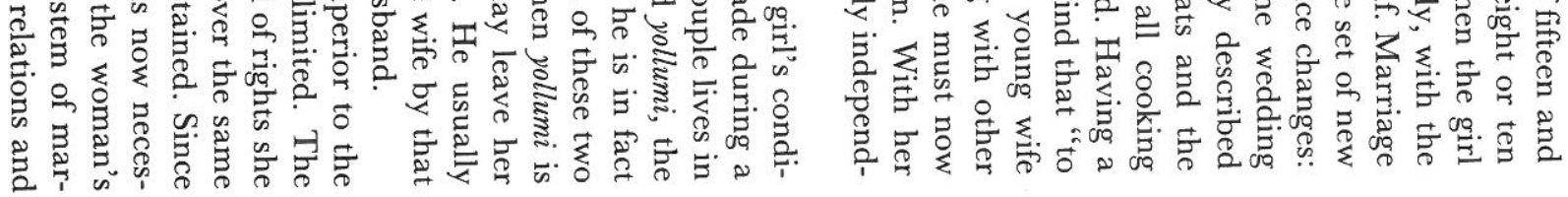

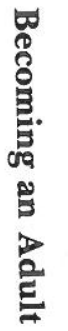

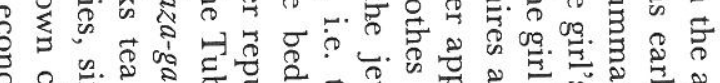

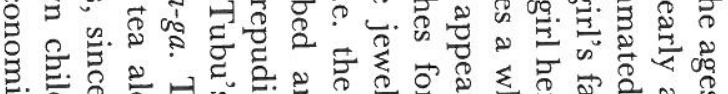
들.

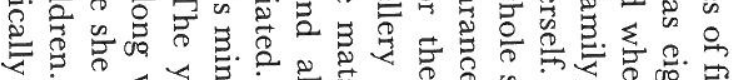

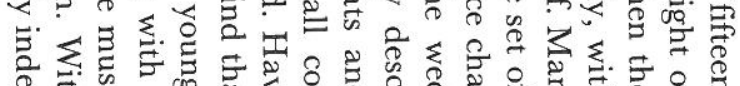

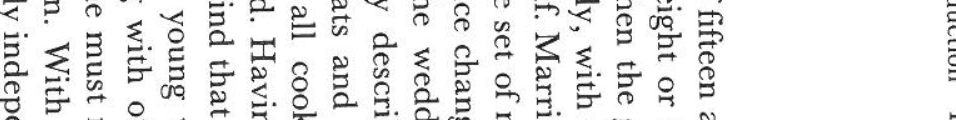




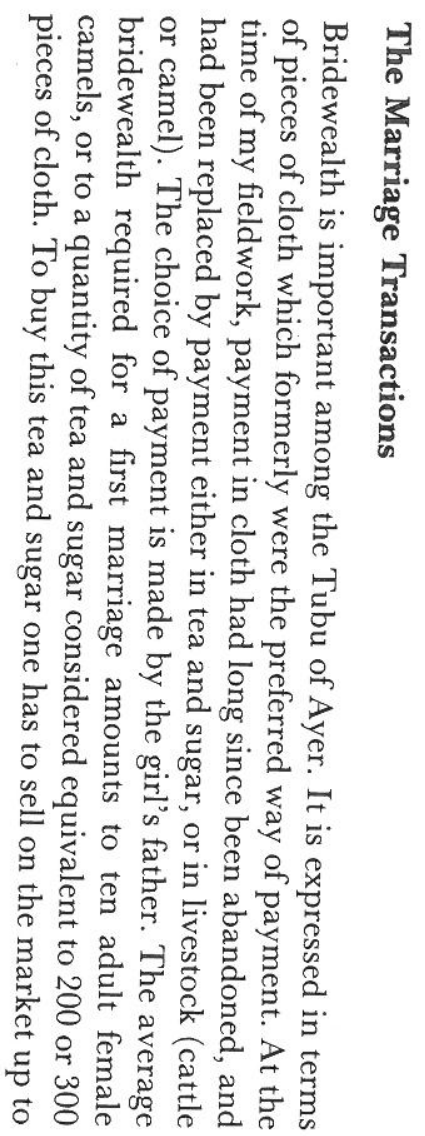

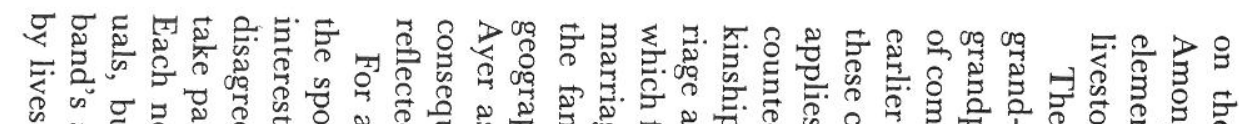

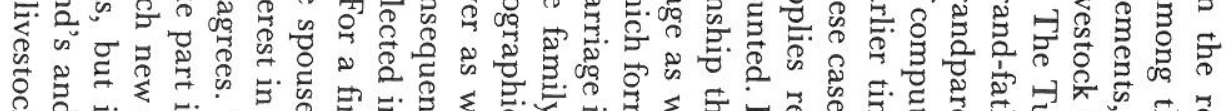

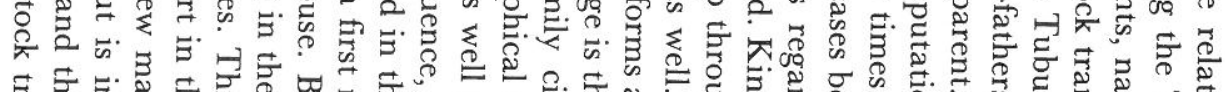

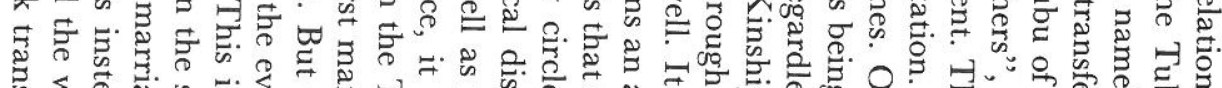

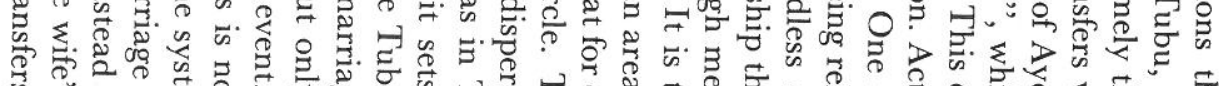
फ

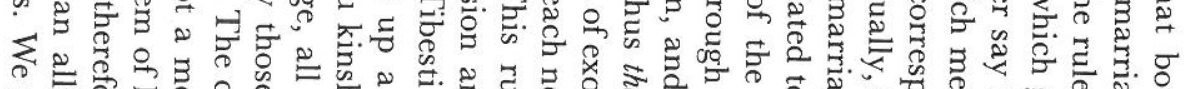

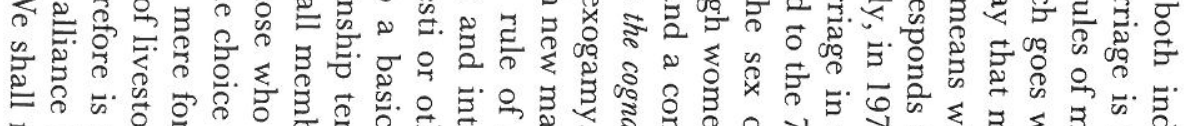

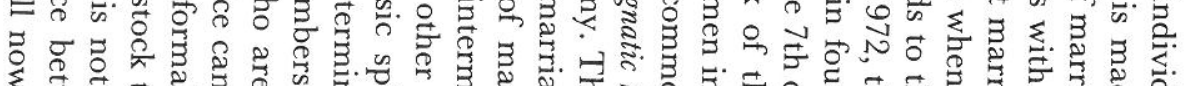

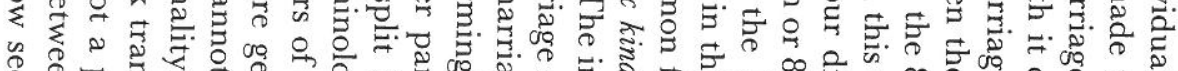

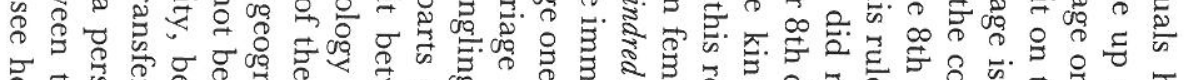

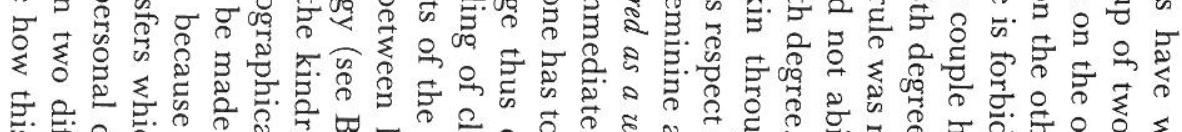

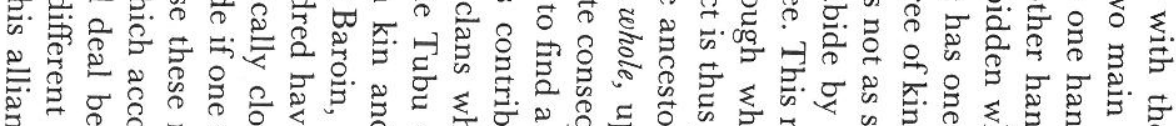

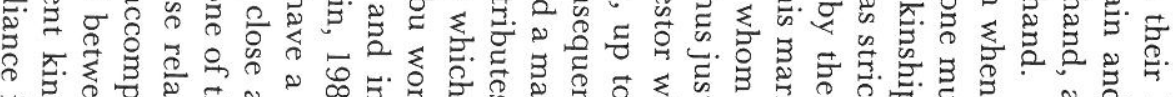
ज.

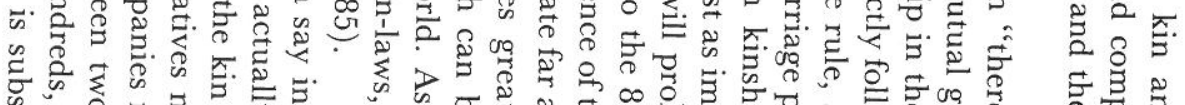

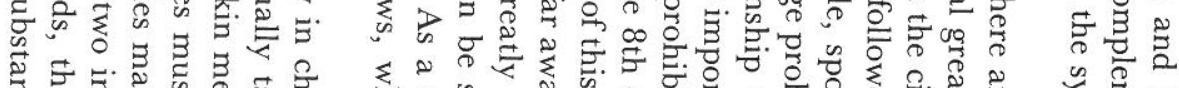

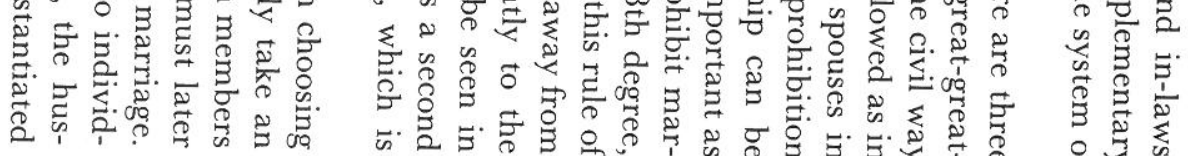

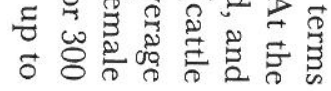

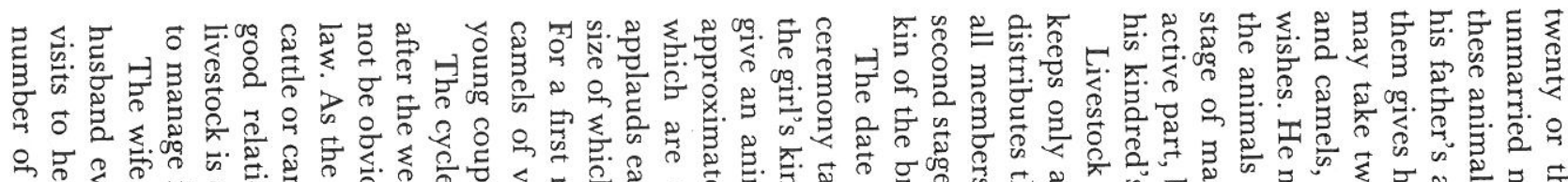

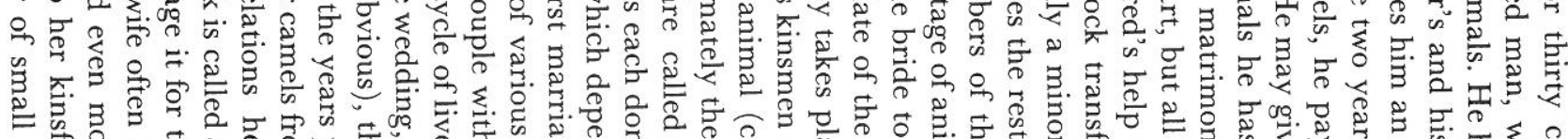

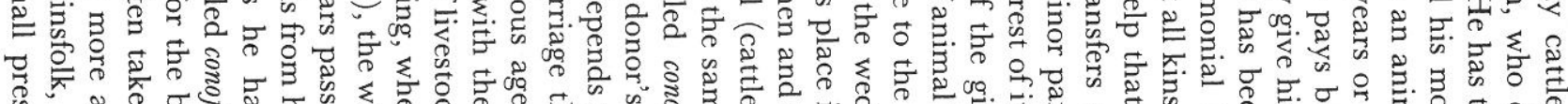

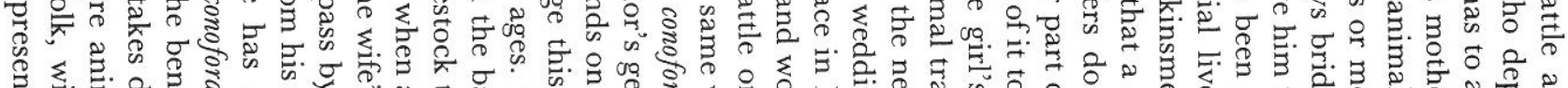

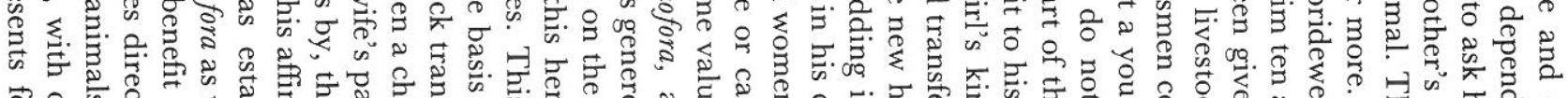

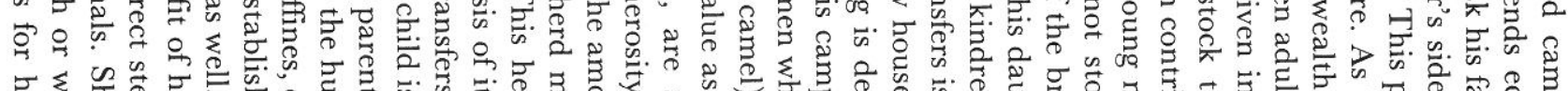

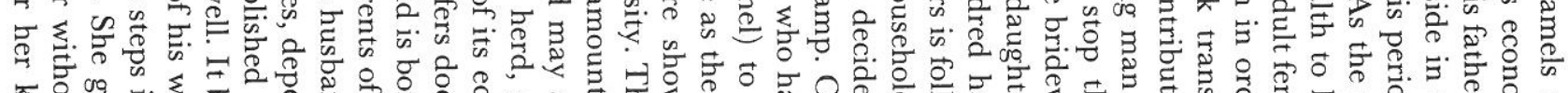

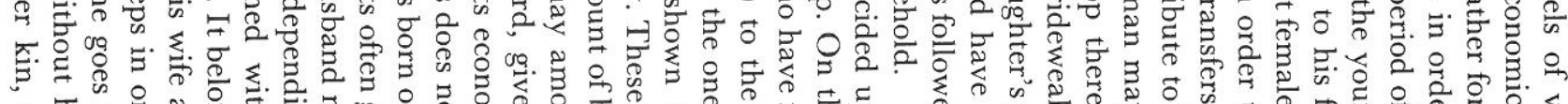

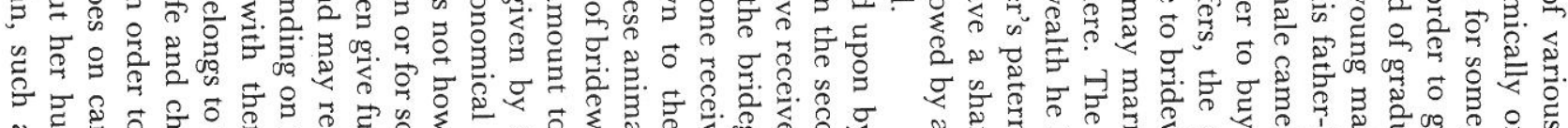

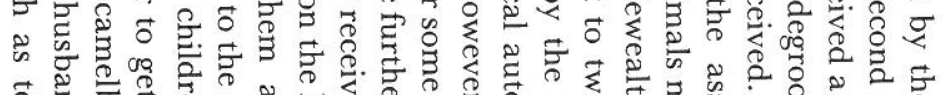

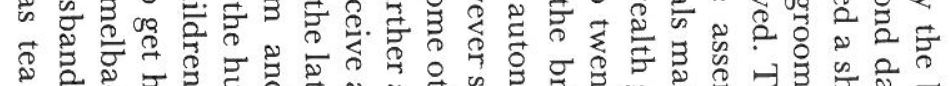

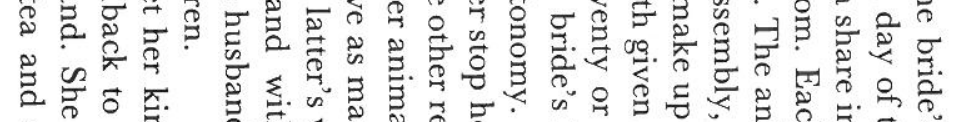

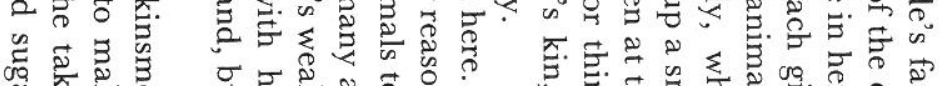

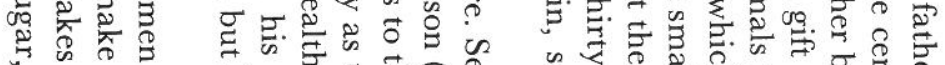

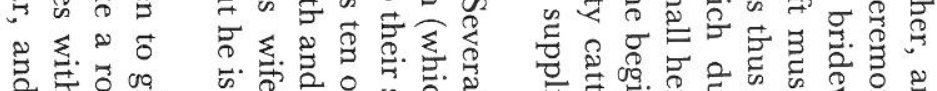

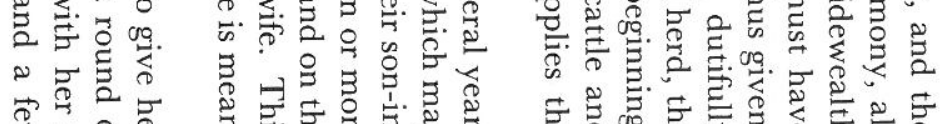
के

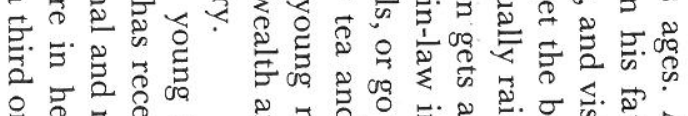

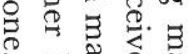

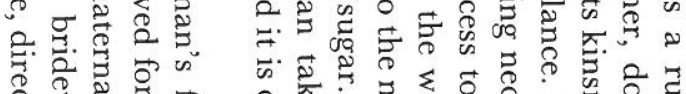

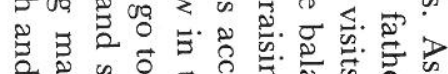

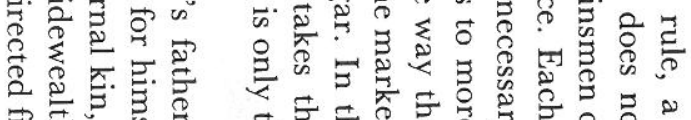

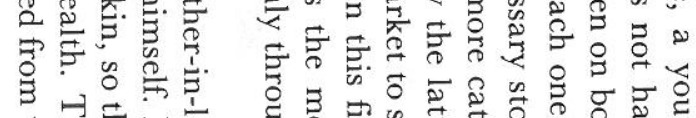

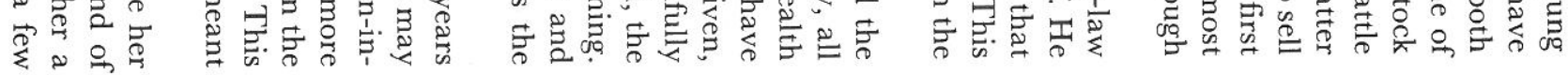




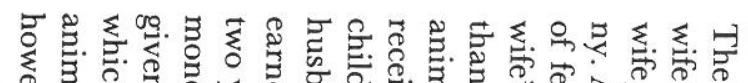

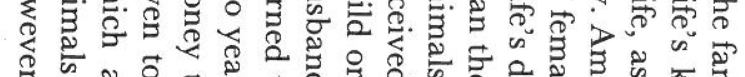

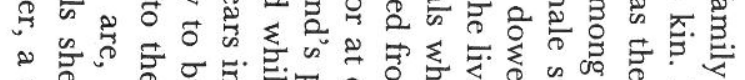

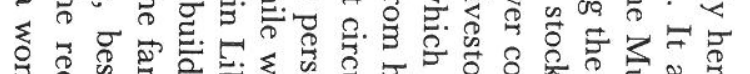

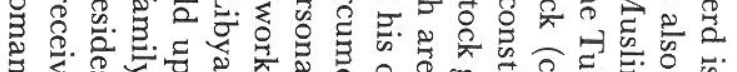

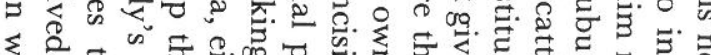

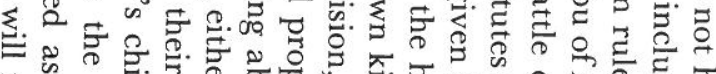

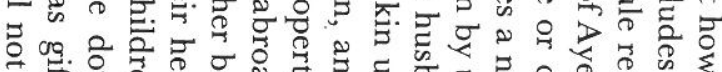

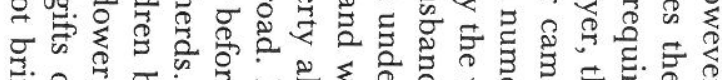

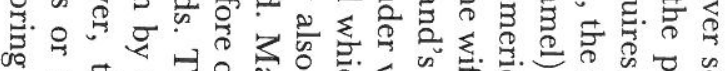

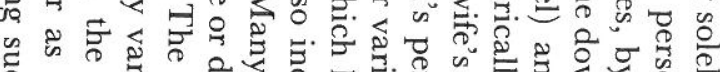

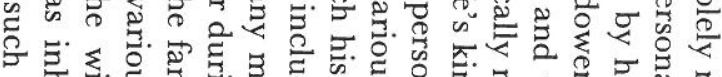

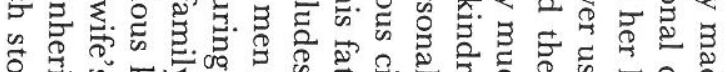

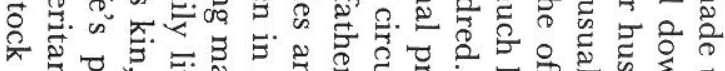

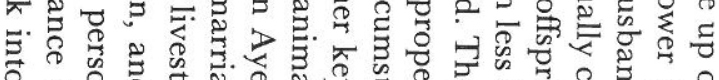

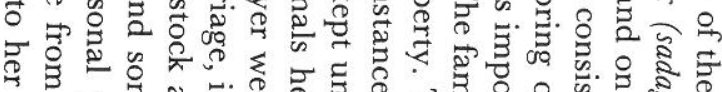

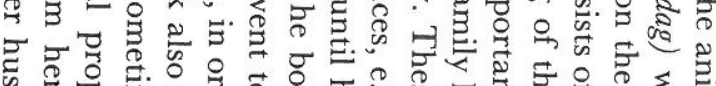

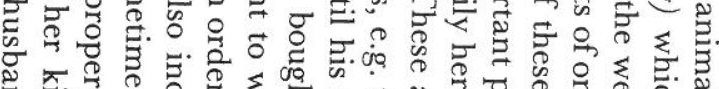

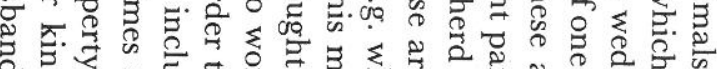
운.

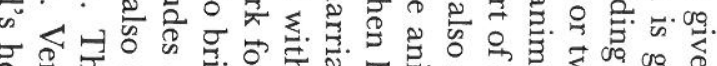

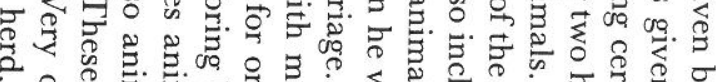
2.

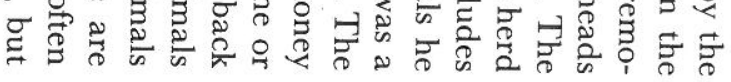

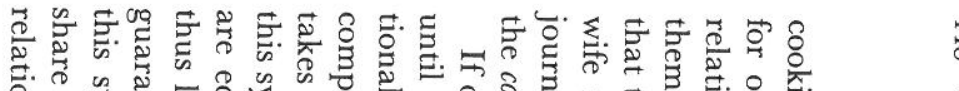

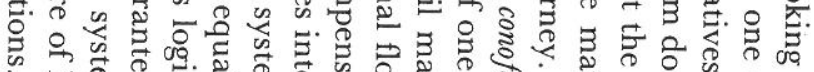

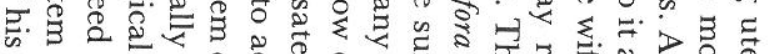

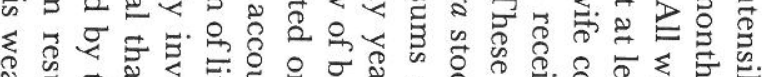

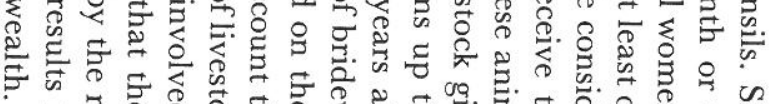

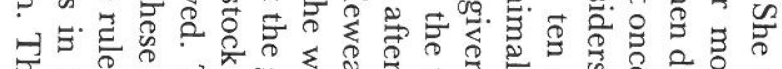

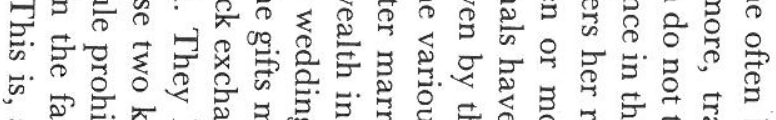

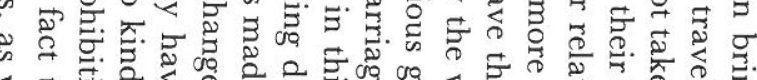

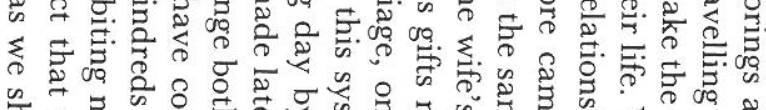

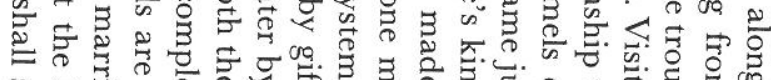

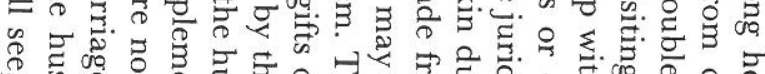

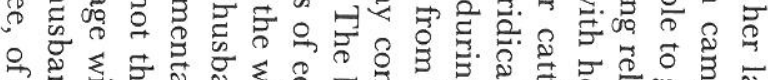

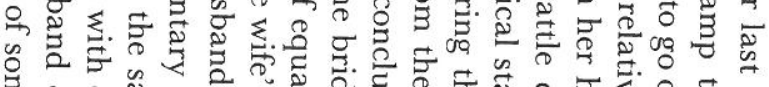

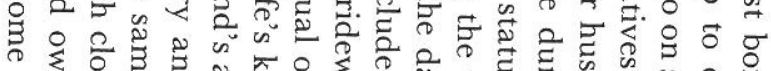
క.

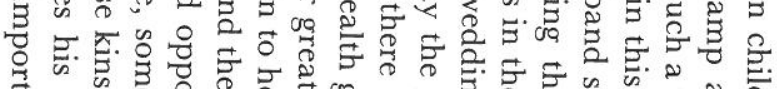

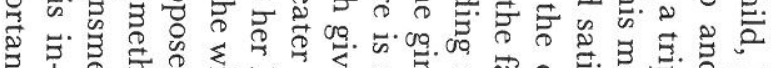
है

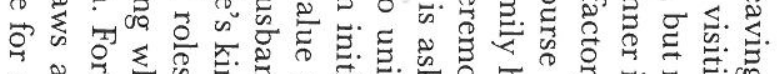

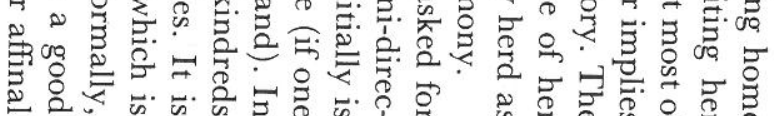

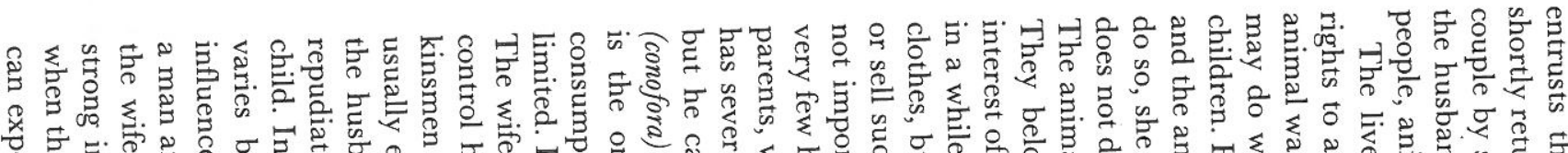

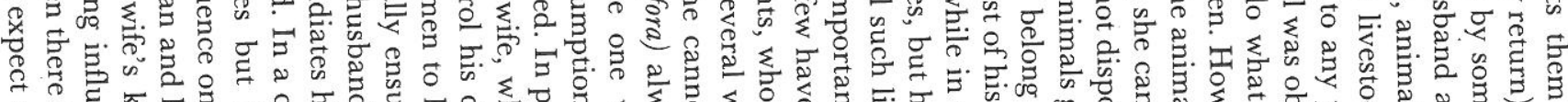

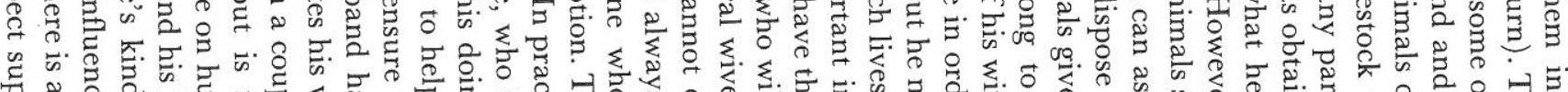
栲

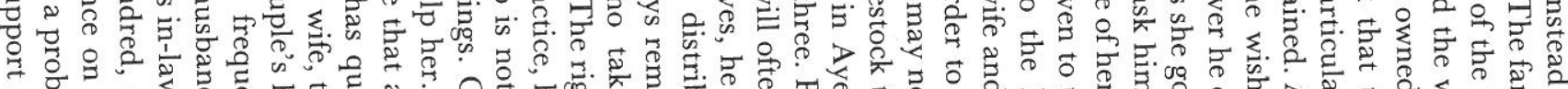

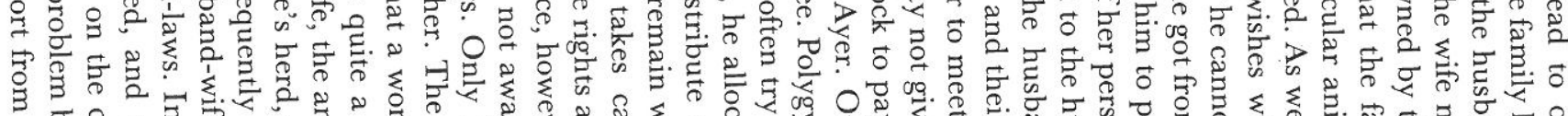

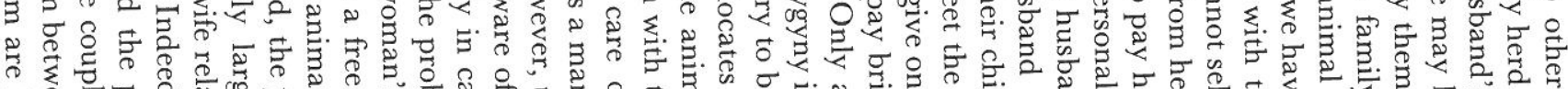

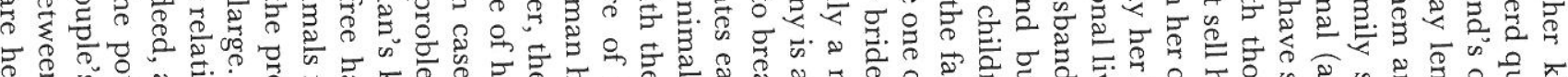

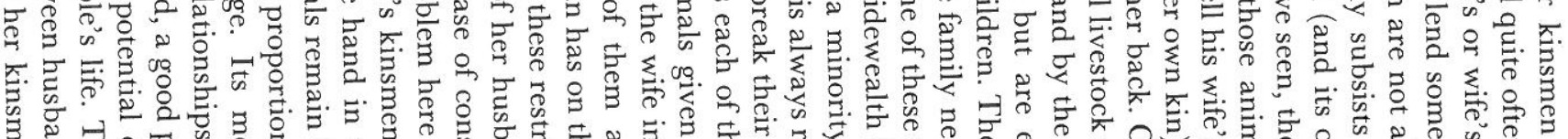

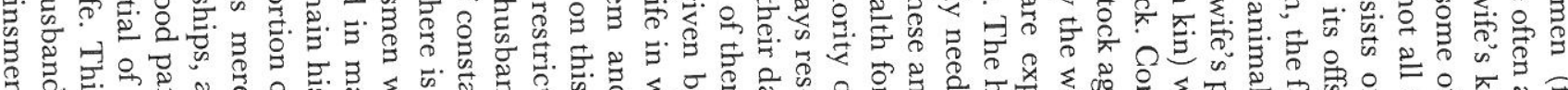

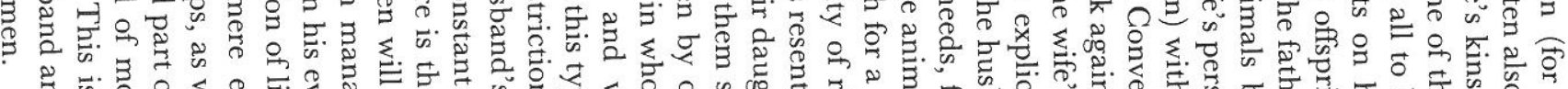

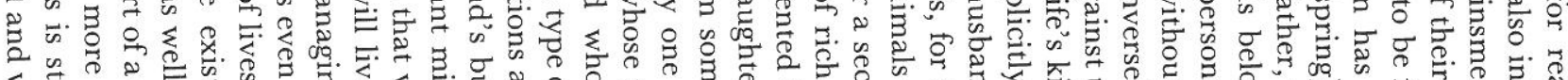

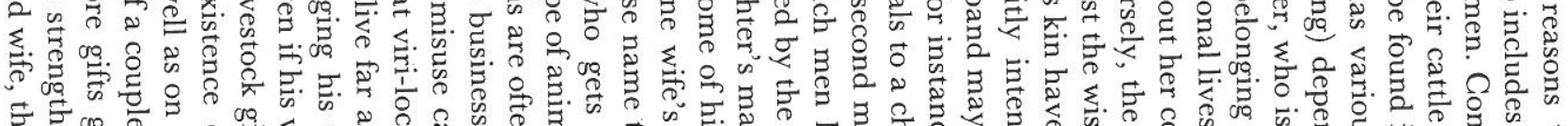

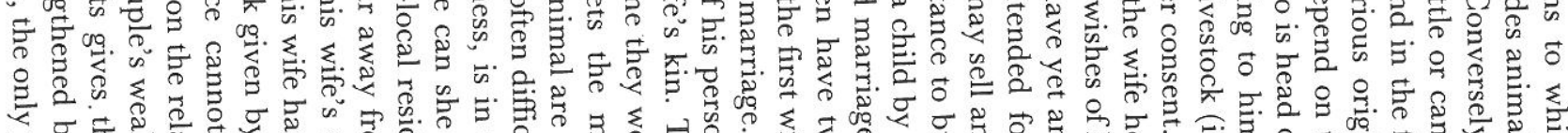

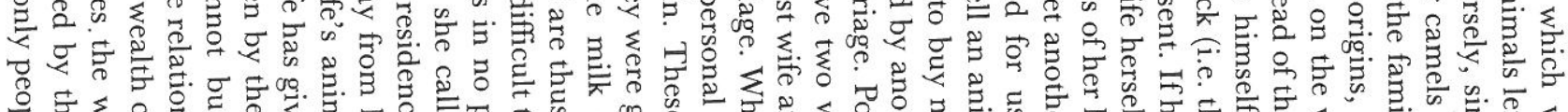

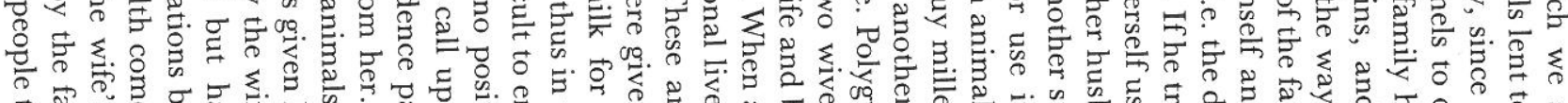

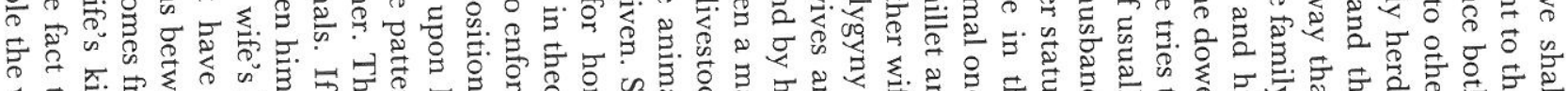

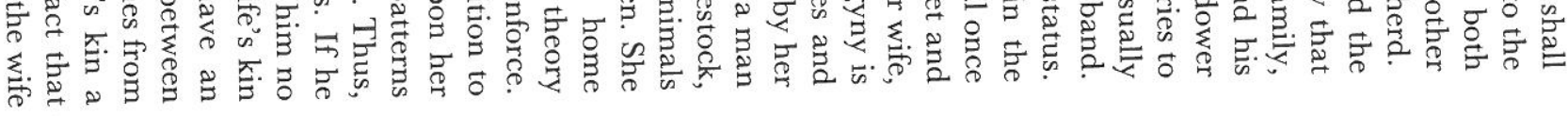




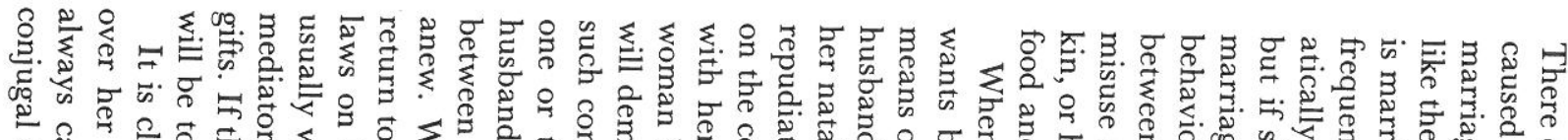

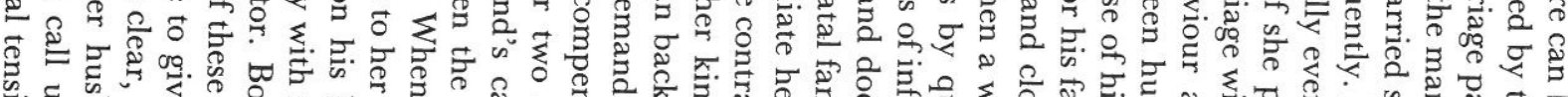

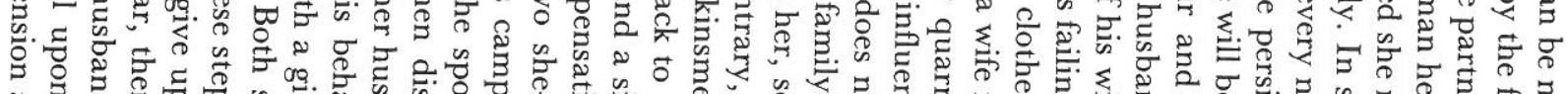

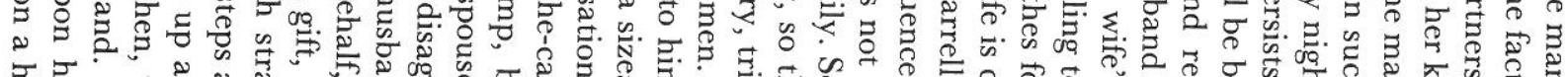

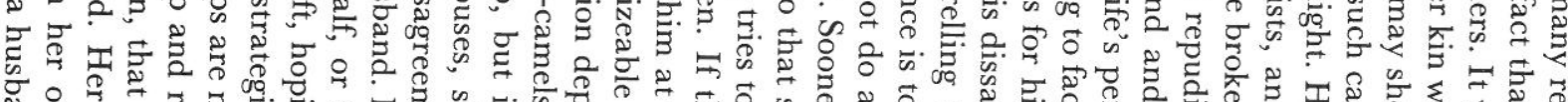

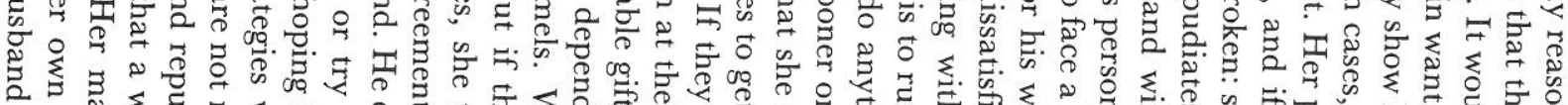

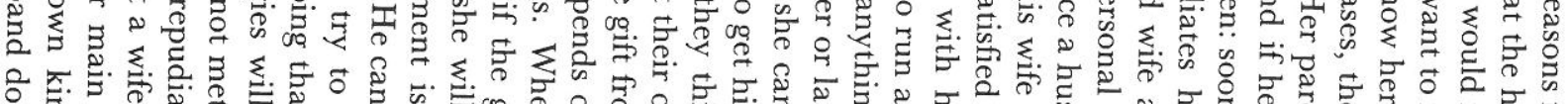

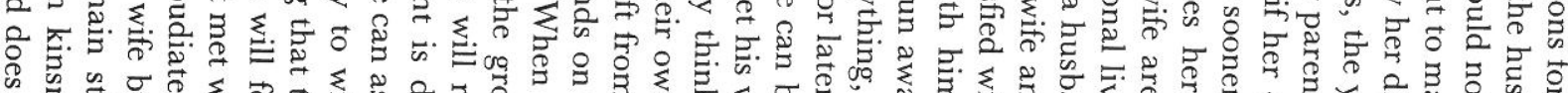

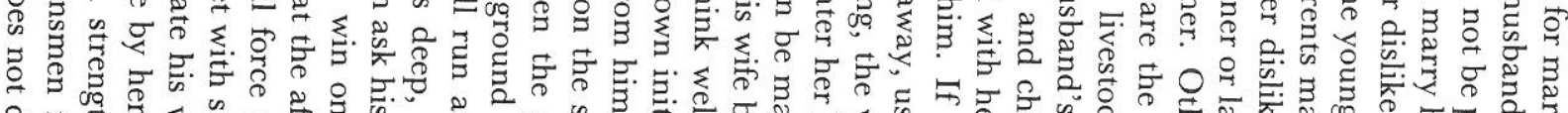

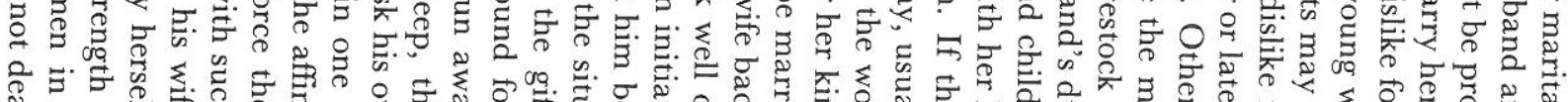

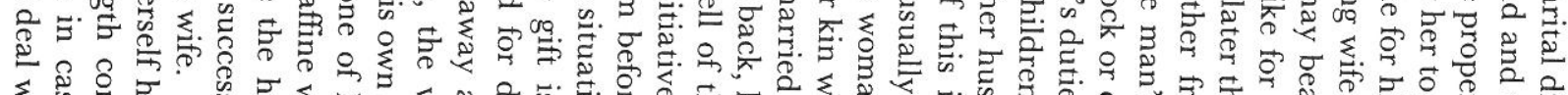

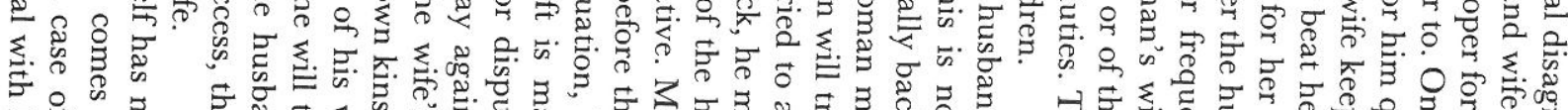

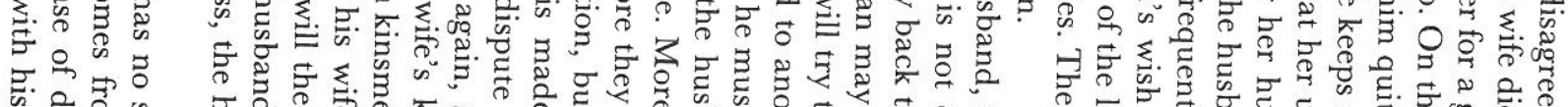

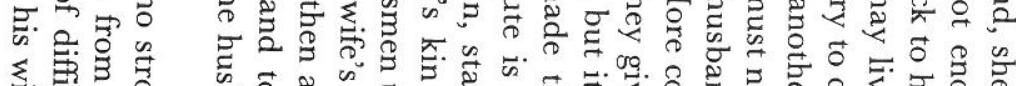

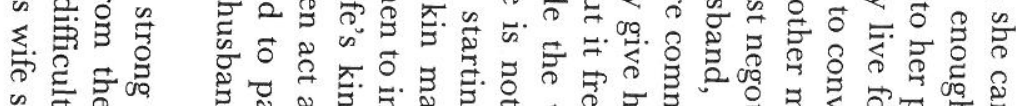

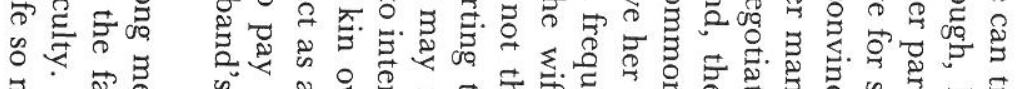

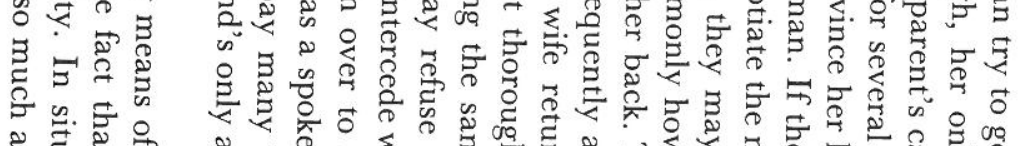

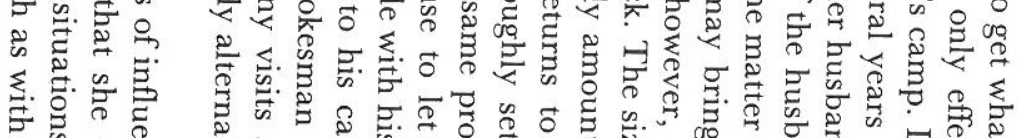

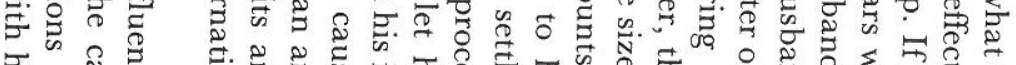

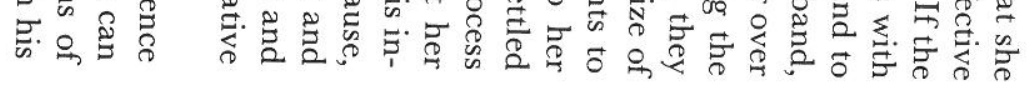

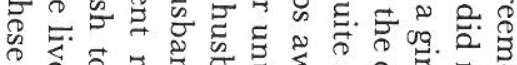

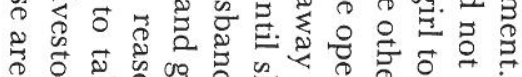

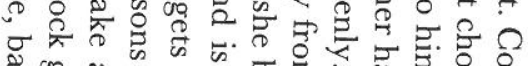

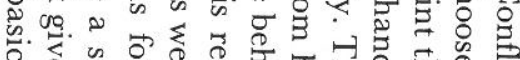

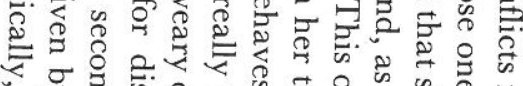

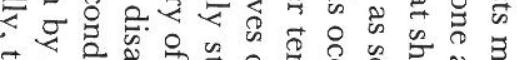

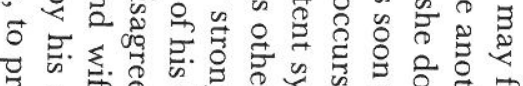

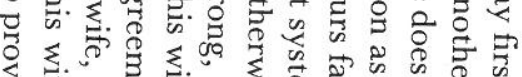

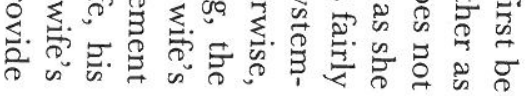

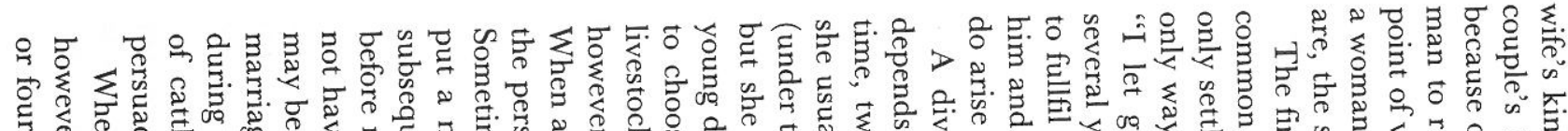

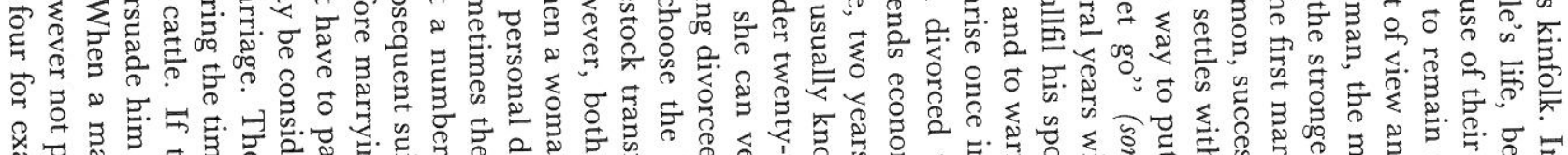

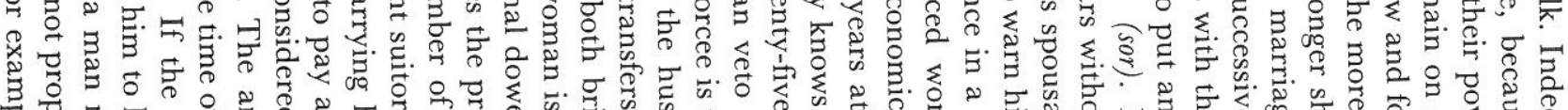

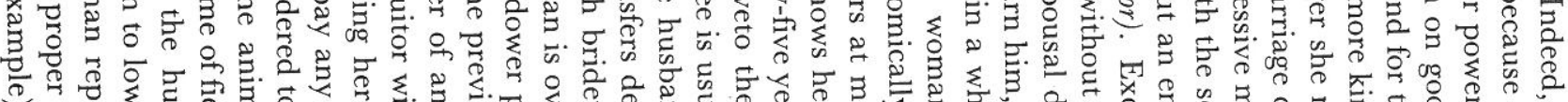

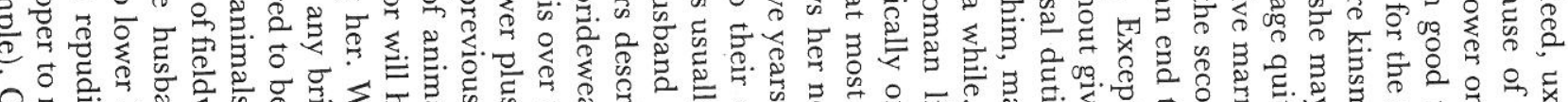

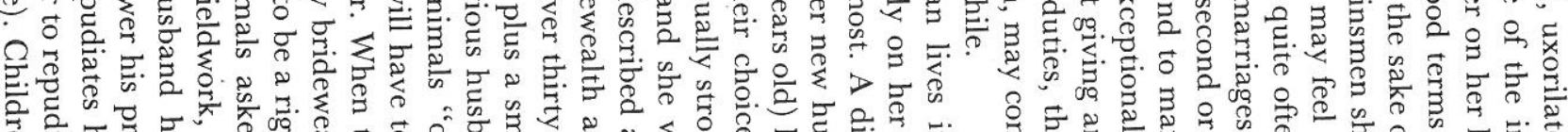

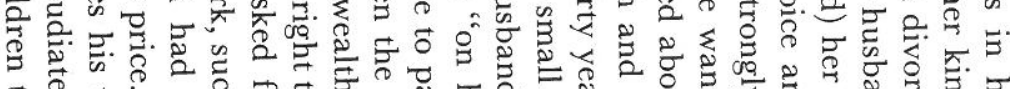

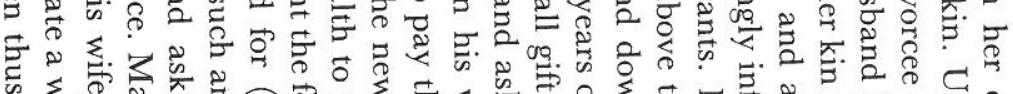

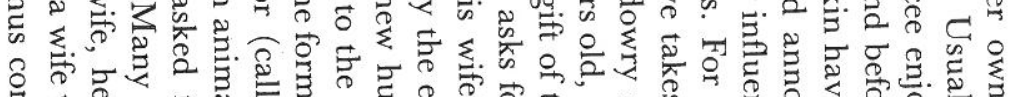

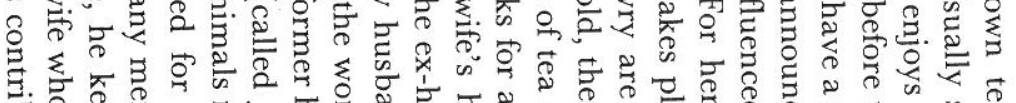

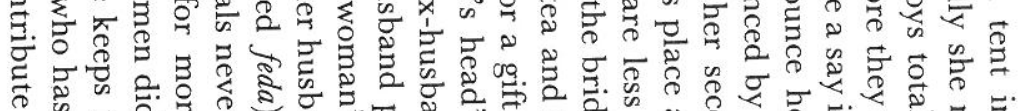

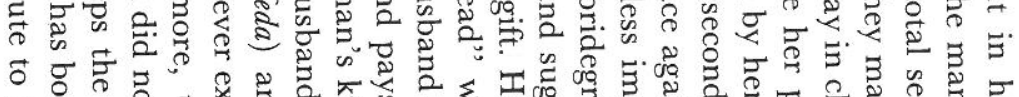

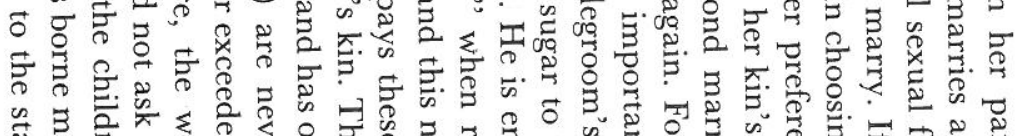

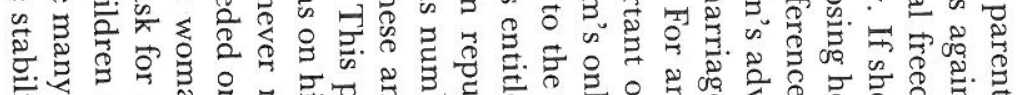

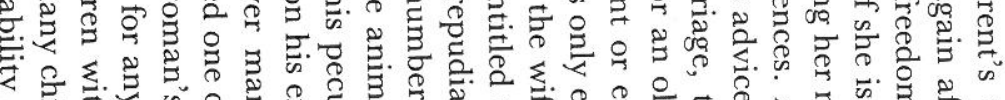

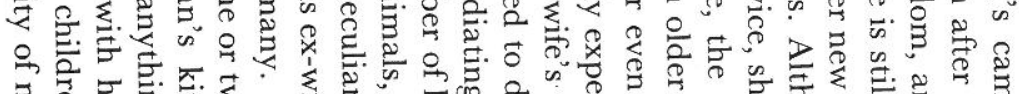

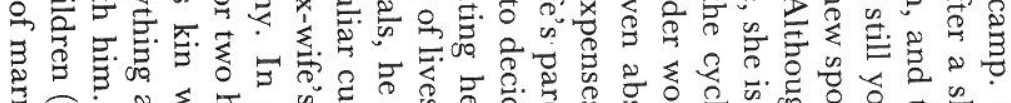

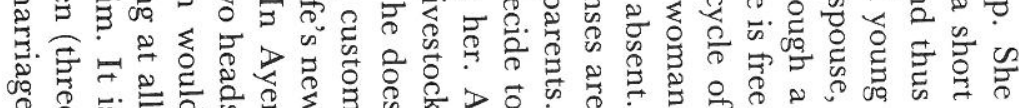

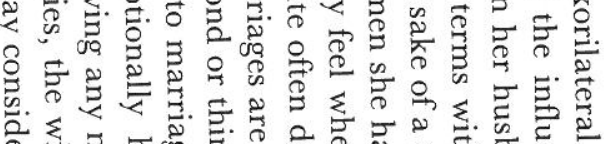

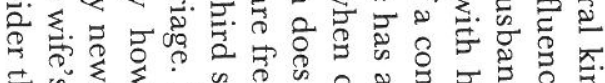

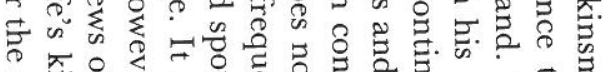

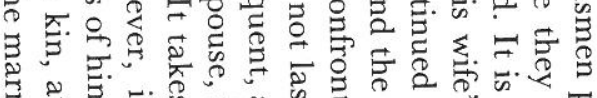

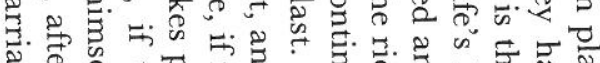

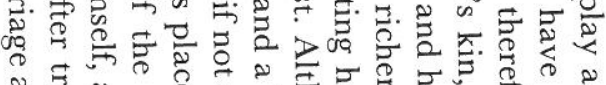

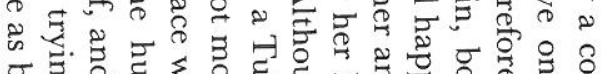

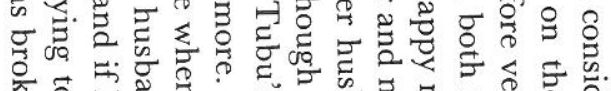

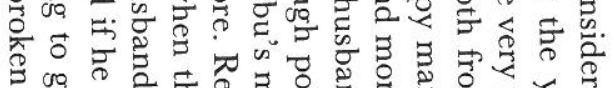

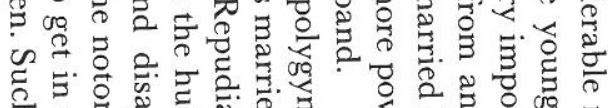

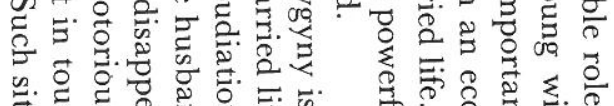

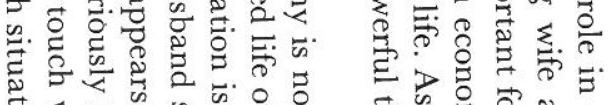

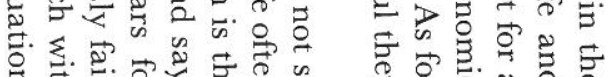




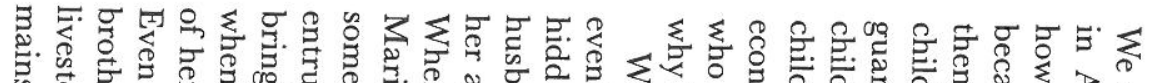

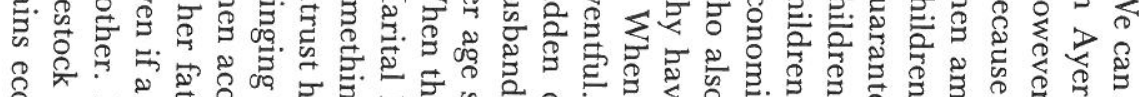

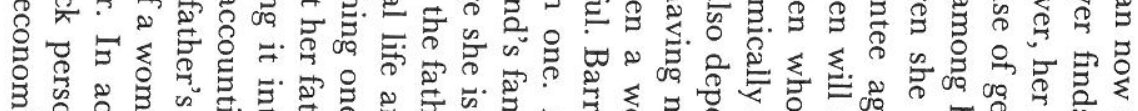

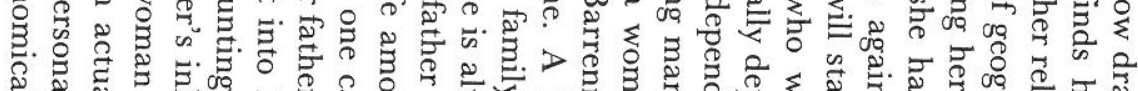

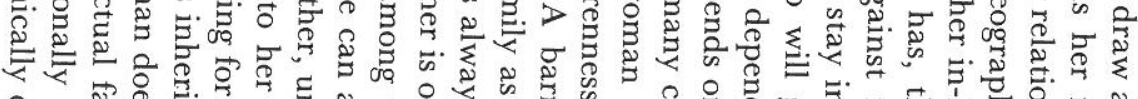

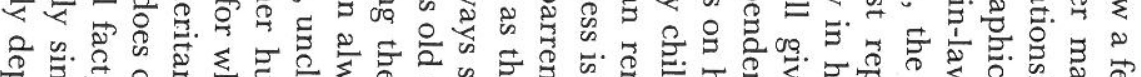

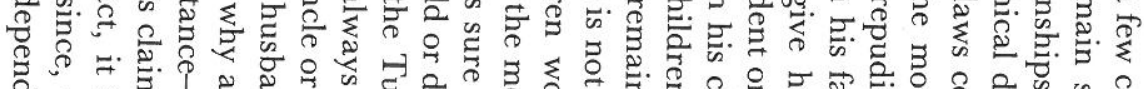

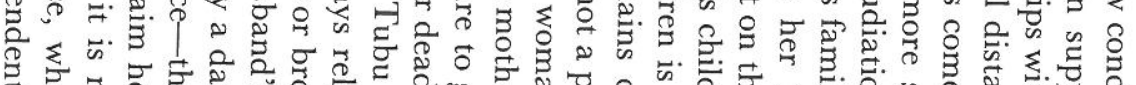

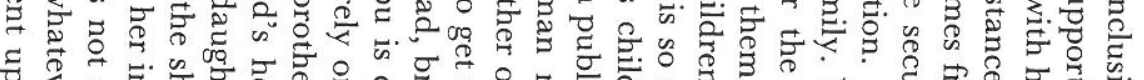

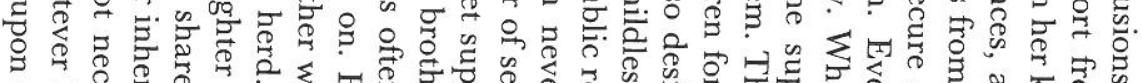

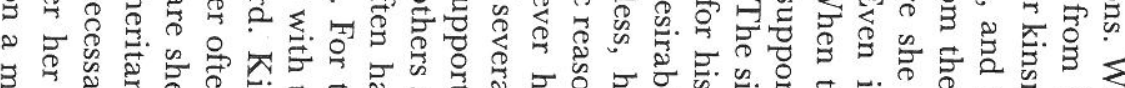

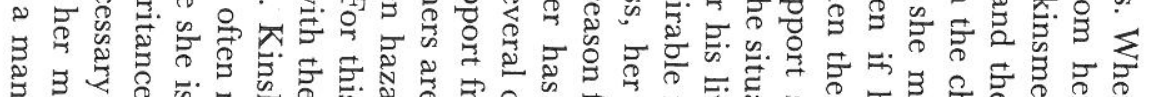

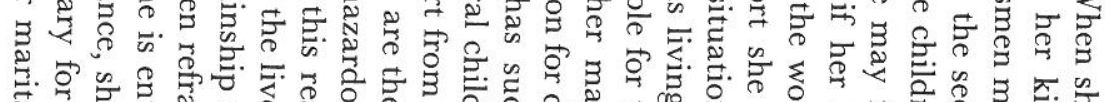

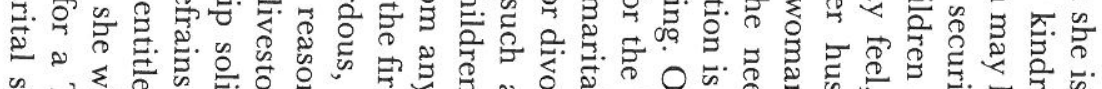

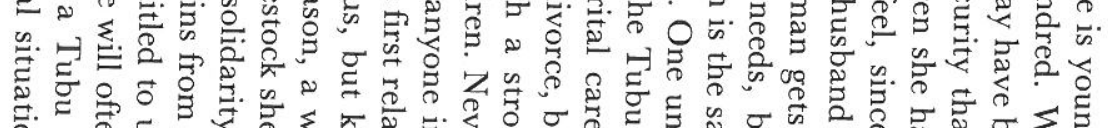

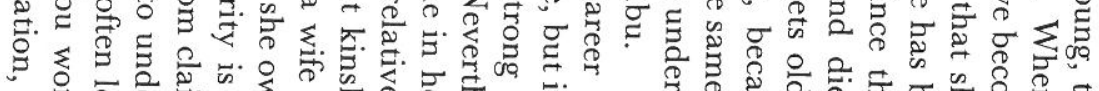

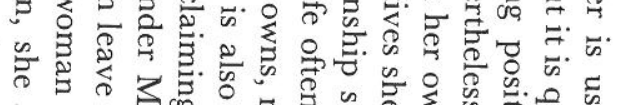

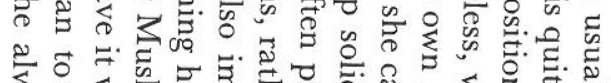

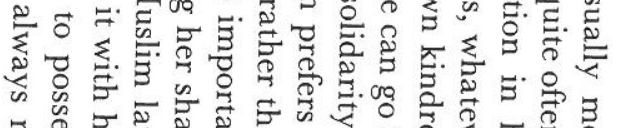

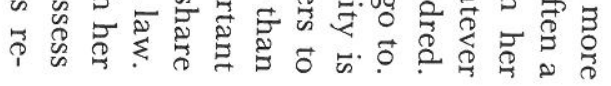

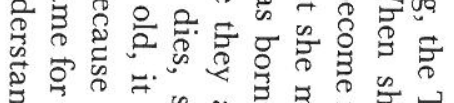

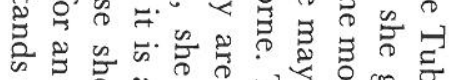

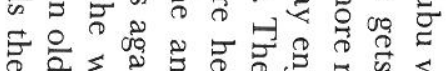

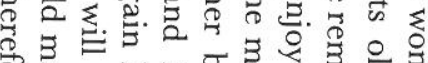

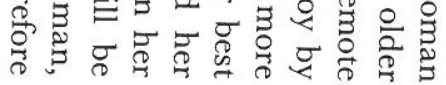

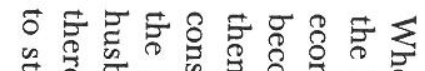

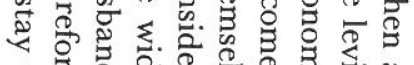

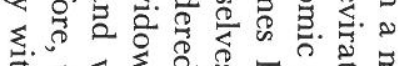

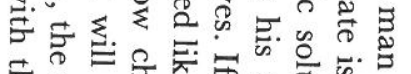

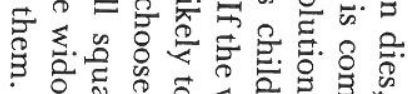

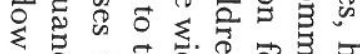

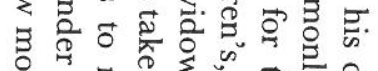
要

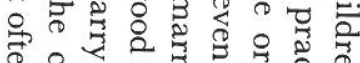

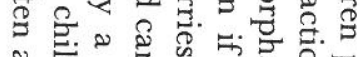

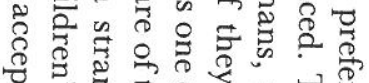

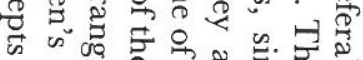

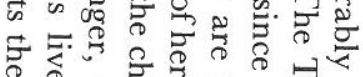

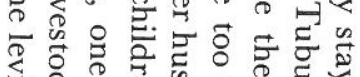

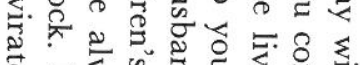
s.

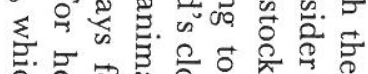

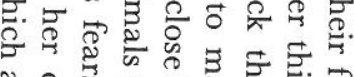

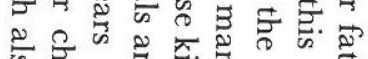

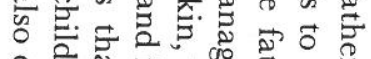

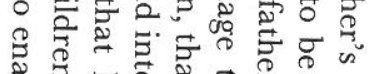

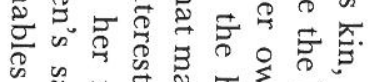

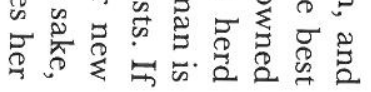

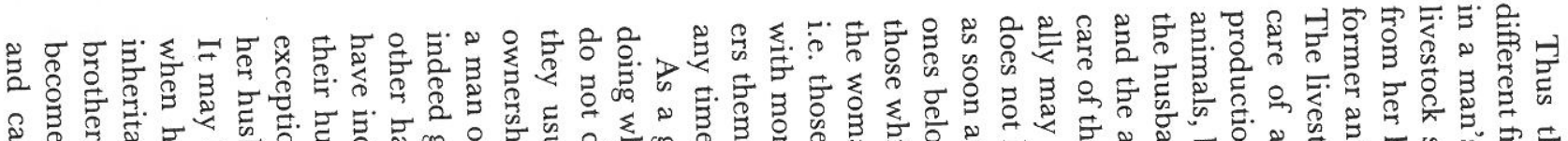

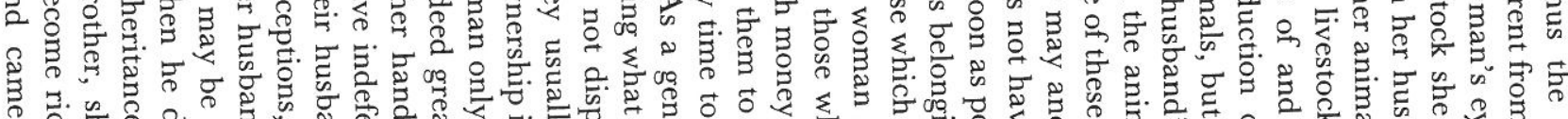

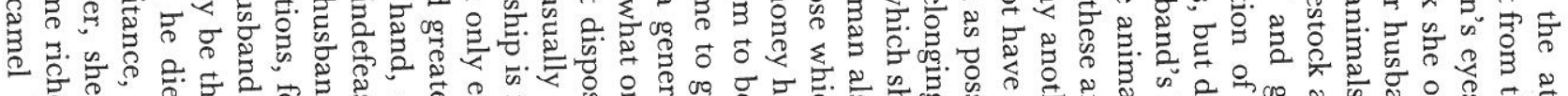

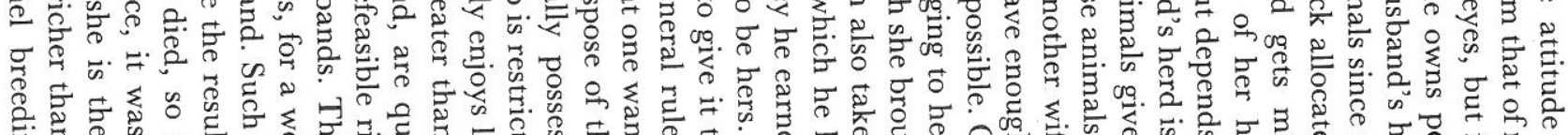

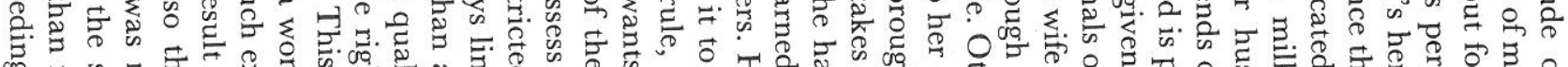

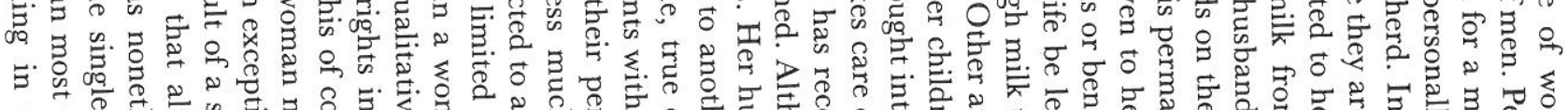

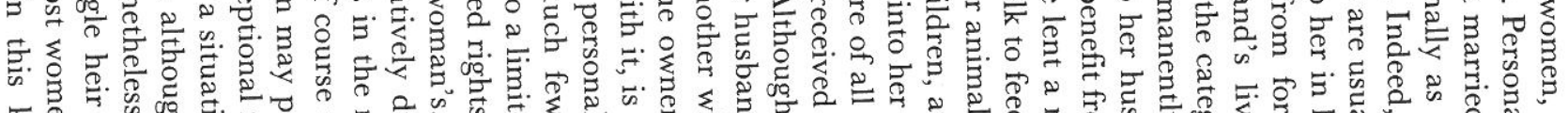

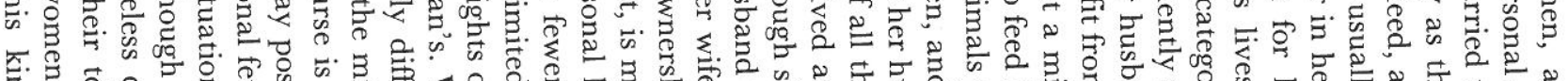

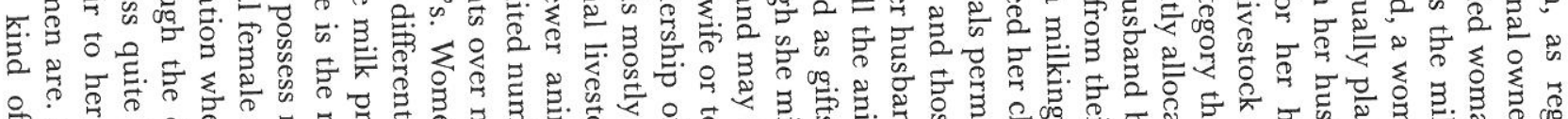

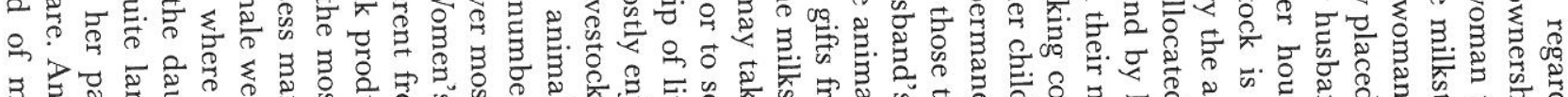

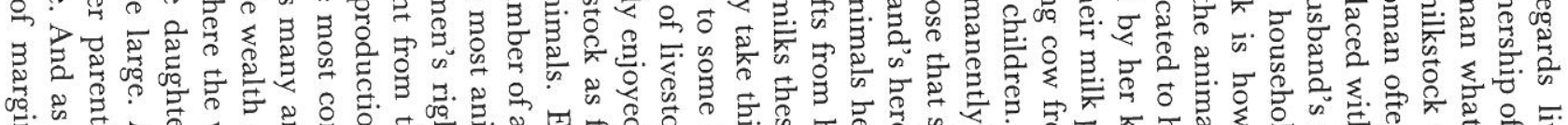

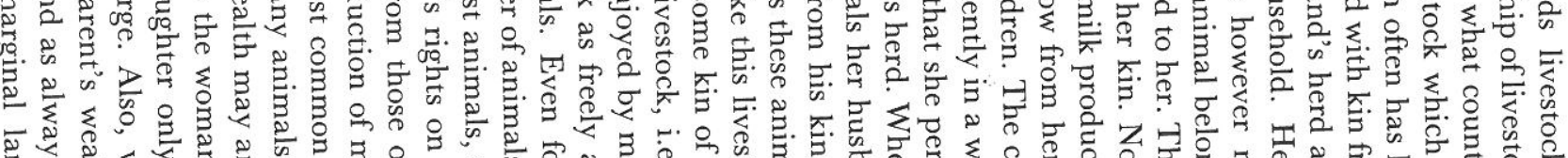

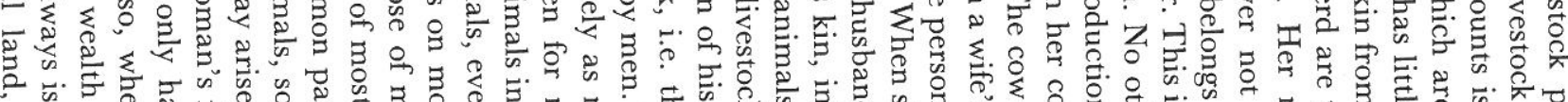

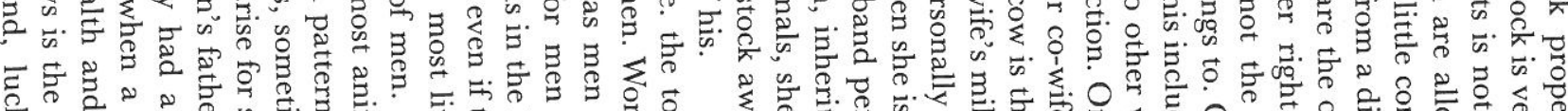

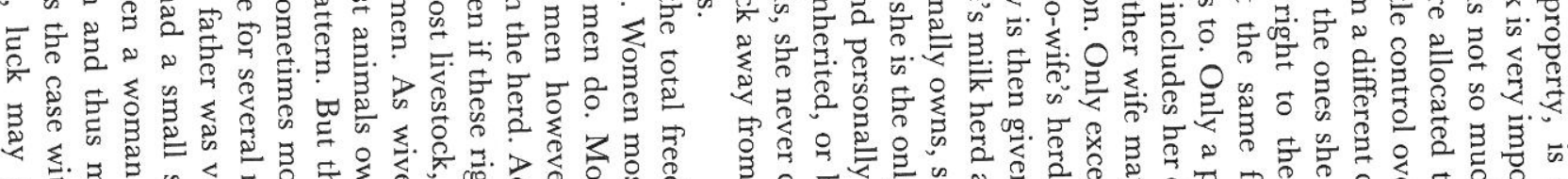

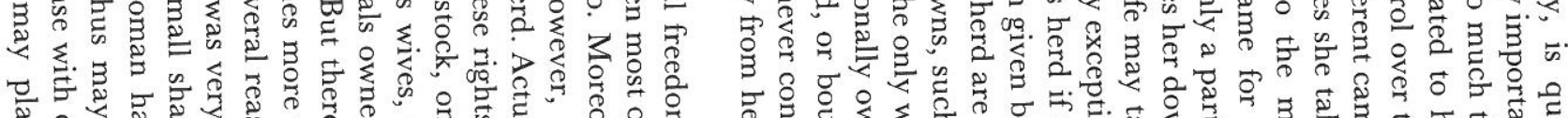

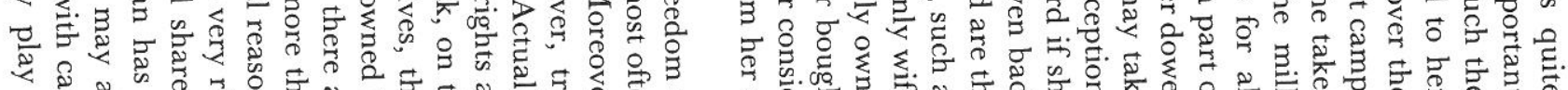

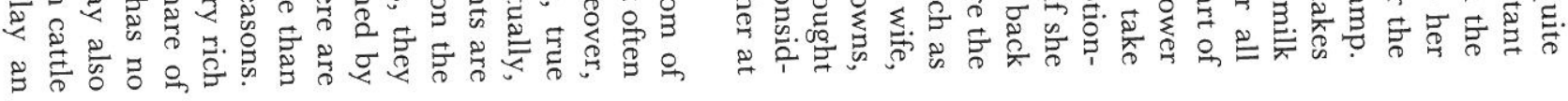




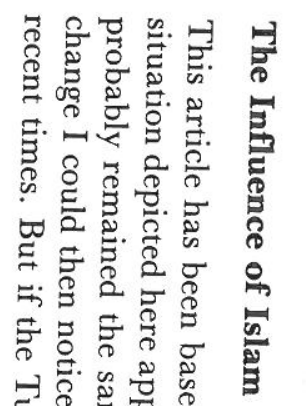

E

.

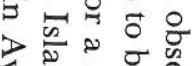

象. $\bar{\circ}$

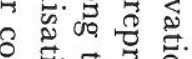

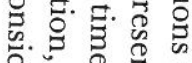

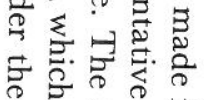

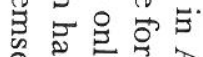

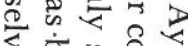

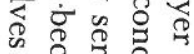

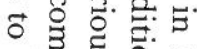

o

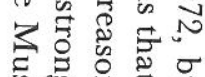

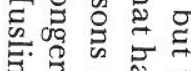

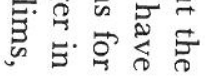

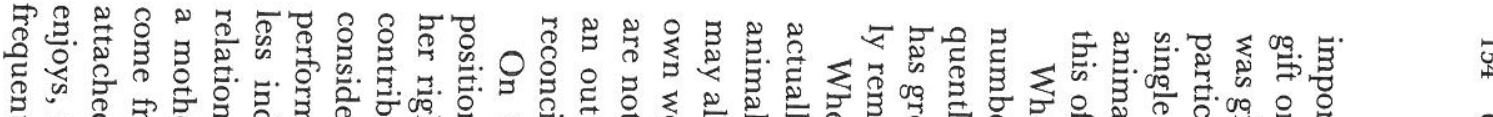

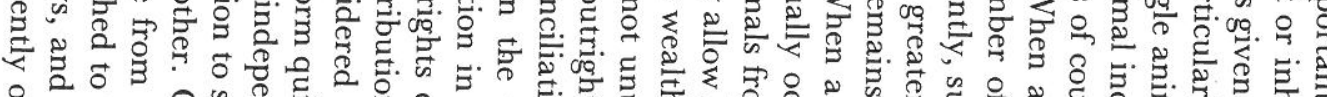

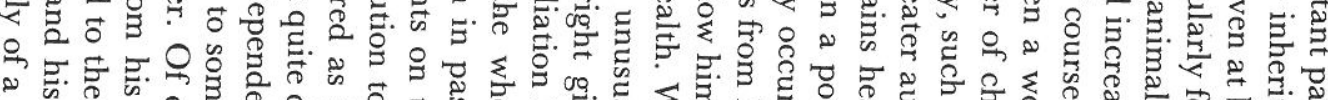

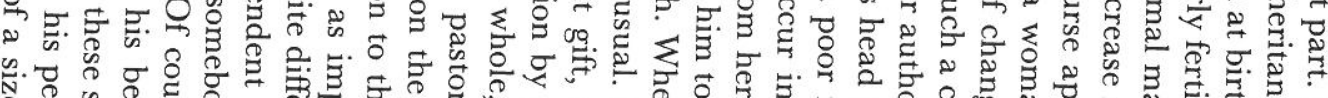

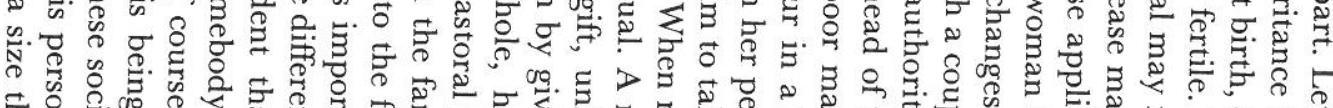

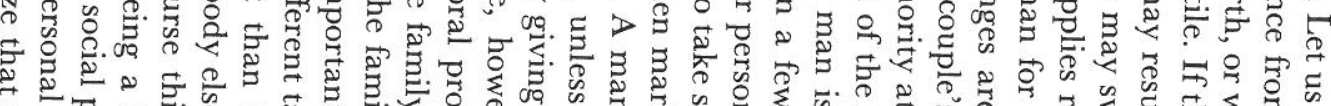

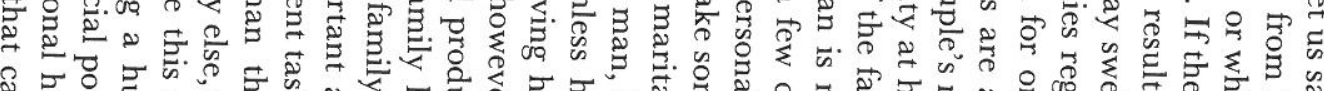

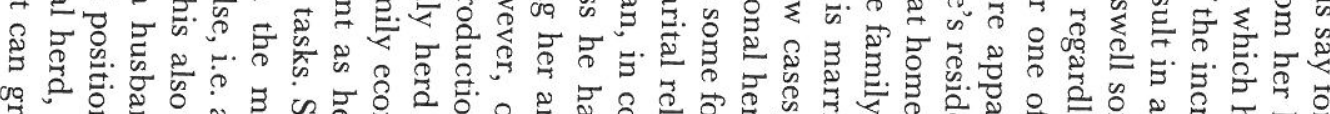

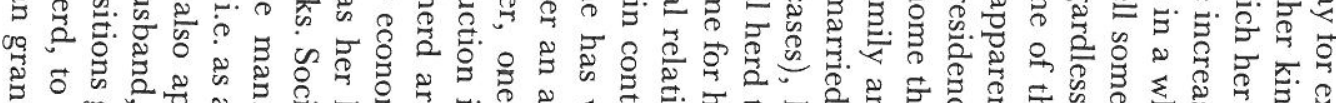

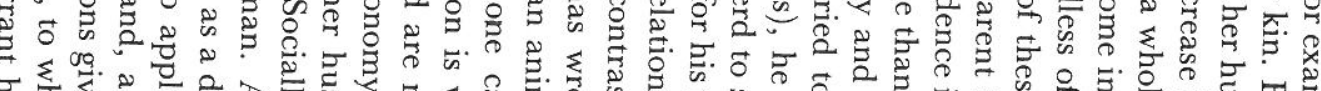

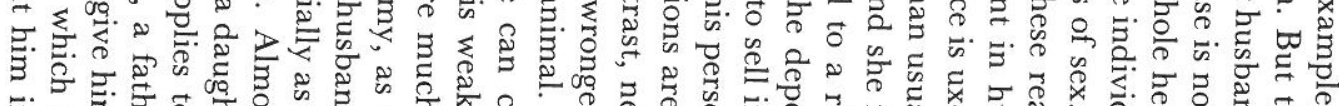

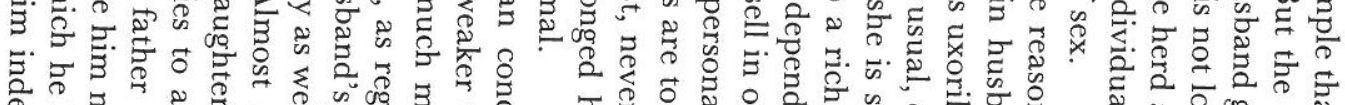

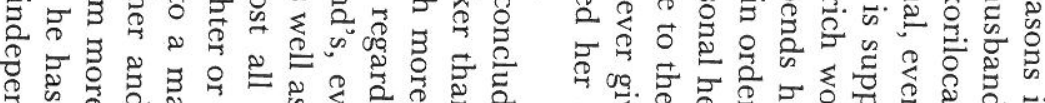

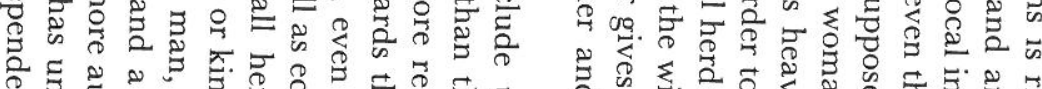

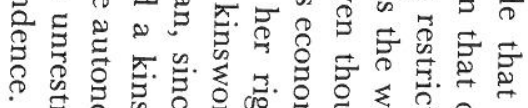

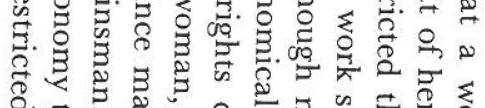

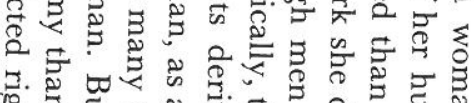

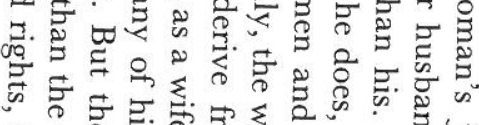

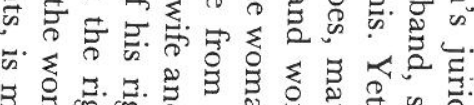

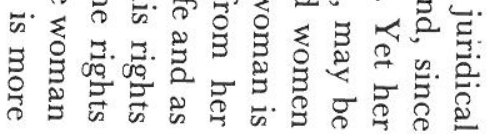

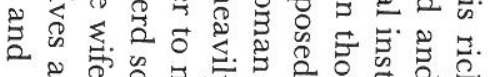

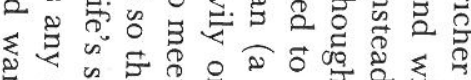

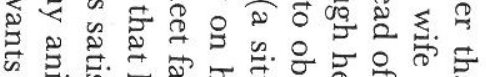

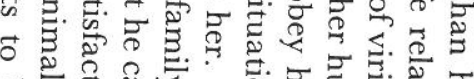

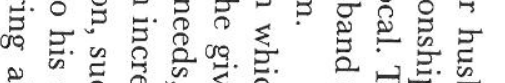

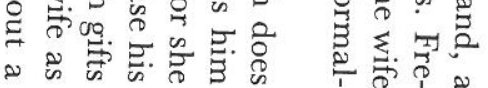

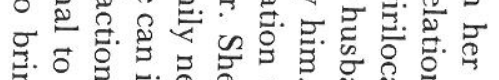

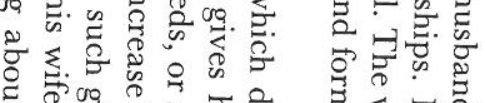

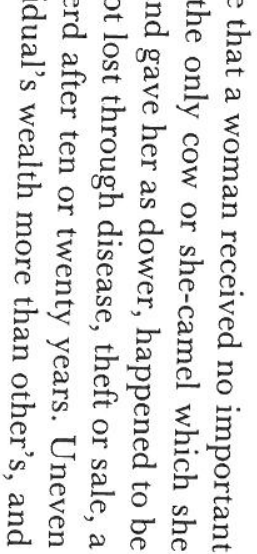

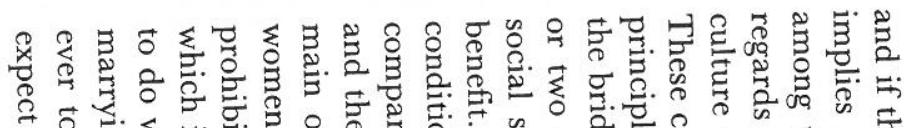

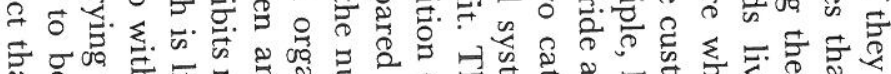

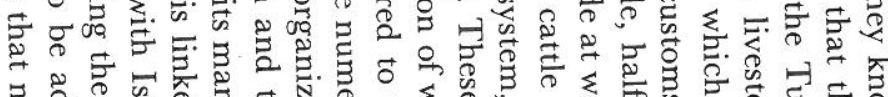

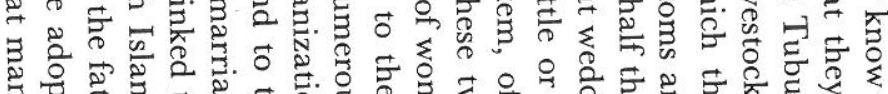

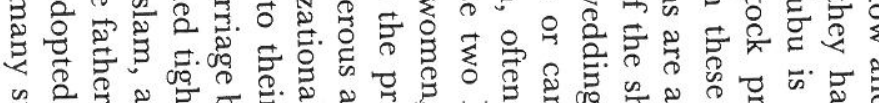

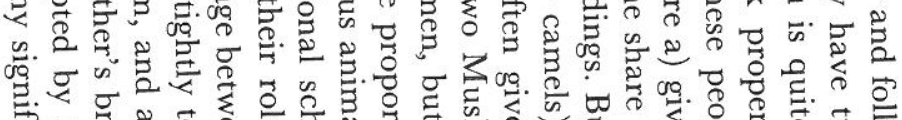

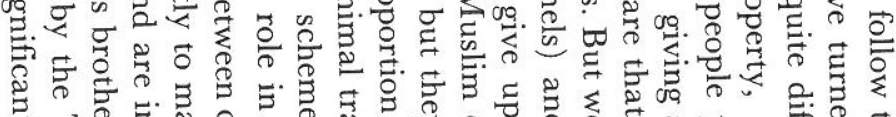

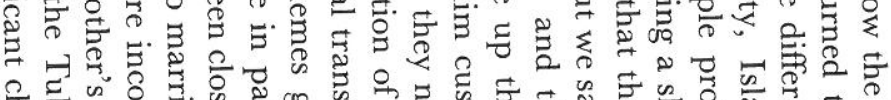

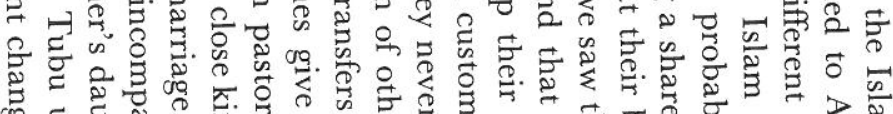

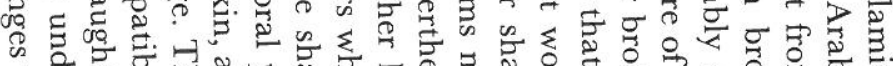

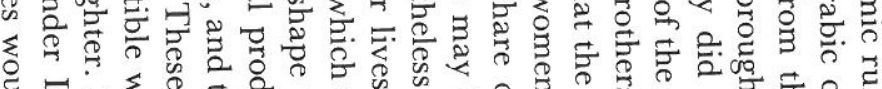

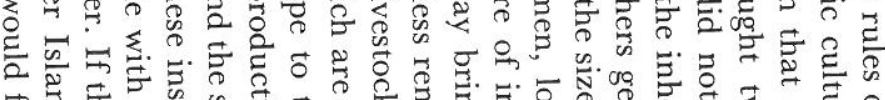

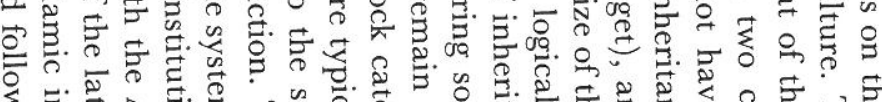

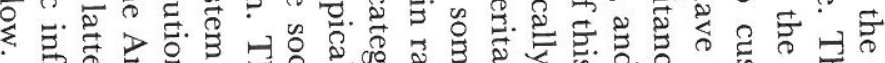

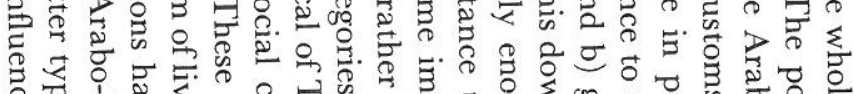

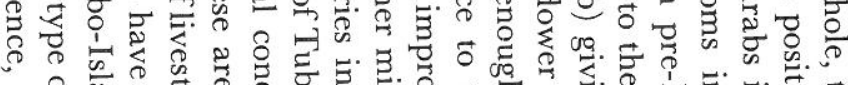

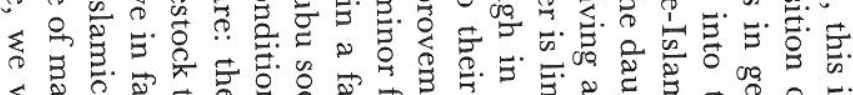

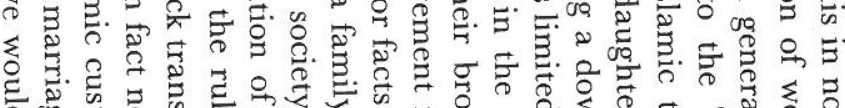

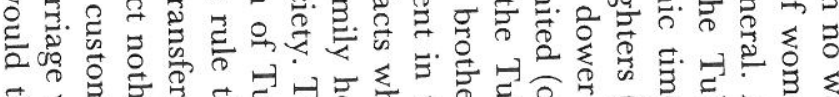

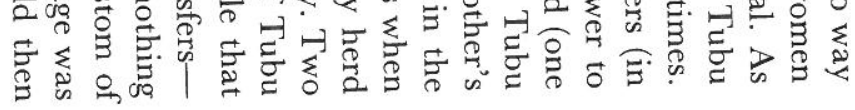

